Supporting Information for:

Redox-Controlled and Reversible N-N Bond Forming and Splitting with an Iron ${ }^{\text {IV }}$ Te rminal Imido Ligand

J. Rolando Aguilar-Calderón, ${ }^{\dagger}$ Dominik Fehn, $₫$ Dieter Sorsche, ${ }^{\dagger}$ Matthias Miehlich, $₫$, Patrick J. Carroll, ${ }^{\dagger}$ Ethan Zars, ${ }^{\dagger}$ Karsten Meyer, $*, \star$ and Daniel J. Mindiola $*, \dagger$

$\dagger$ Department of Chemistry, University of Pennsylvania, Philadelphia, PA 19104 (USA).

\#norganic Chemistry, Department of Chemistry and Pharmacy, Friedrich-AlexanderUniversity Erlangen-Nürnberg (FAU), 91058 Erlangen (Germany) 


\section{Table of Content}

Electron Paramagnetic Resonance (EPR) Spectroscopy details .........................................4

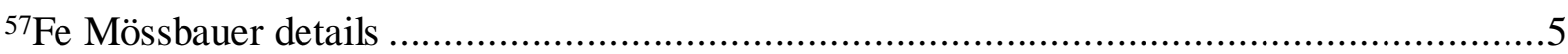

SQUID magnetization measurement details .......................................................

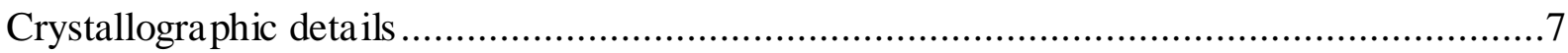

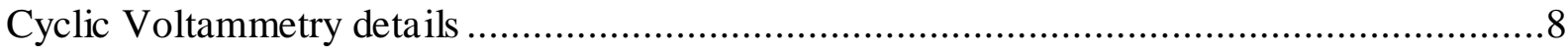

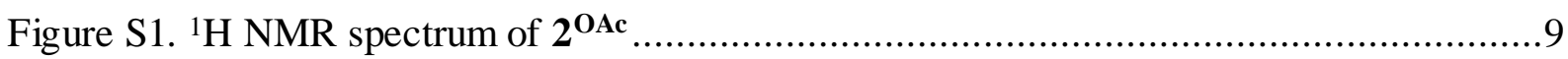

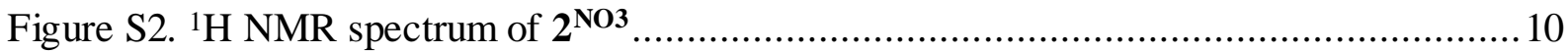

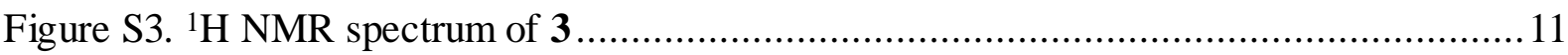

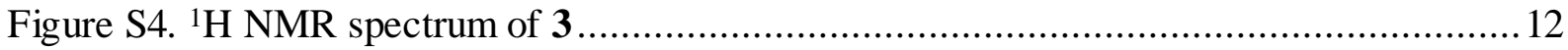

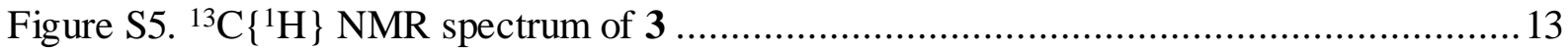

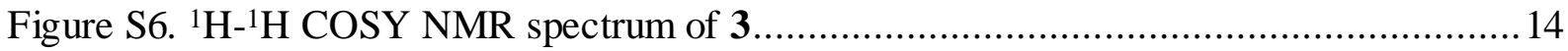

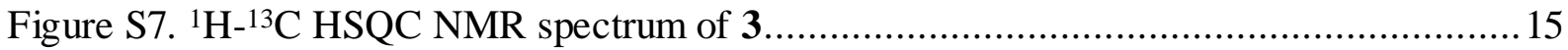

Figure S8. Stacked ${ }^{1} \mathrm{H}$ NMR spectra of the thermal conversion of $\left[\mathrm{Fe}\left(\mathrm{N}\left(\mathrm{SiMe}_{3}\right)_{2}\right)_{2}\right]$ and $\mathbf{3}(\downarrow)$ to

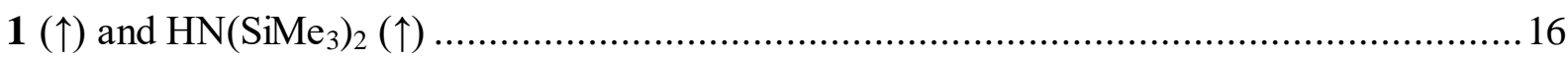

Figure S9. Stacked ${ }^{1} \mathrm{H}$ NMR spectra of the thermal conversion of $\mathrm{Fe}\left(\mathrm{N}\left(\mathrm{SiMe}_{3}\right)_{2}(\downarrow)\right.$ and 3 to

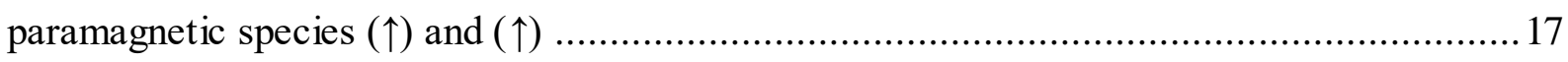

Figure S10. Stacked ${ }^{1} \mathrm{H}$ NMR spectra of the thermal conversion of $\left[\mathrm{Co}\left(\mathrm{N}\left(\mathrm{SiMe}_{3}\right)_{2}\right)_{2}\right]$ and $\mathbf{3}(\downarrow)$

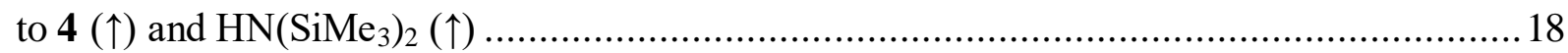

Figure S11. Stacked ${ }^{1} \mathrm{H}$ NMR stacked spectra of the thermal conversion of $\left[\mathrm{Co}\left(\mathrm{N}\left(\mathrm{SiMe}_{3}\right)_{2}\right)_{2}\right]$

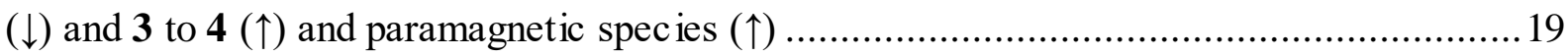

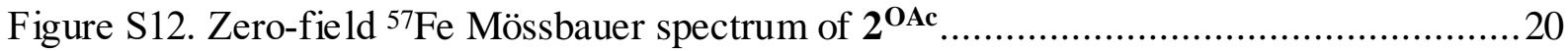

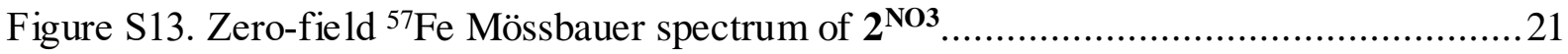

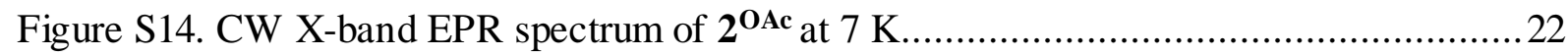

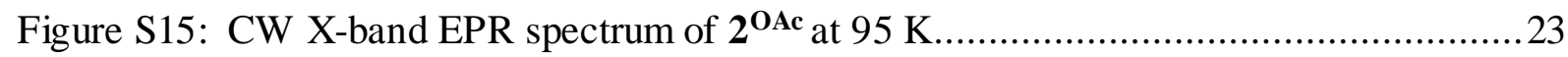




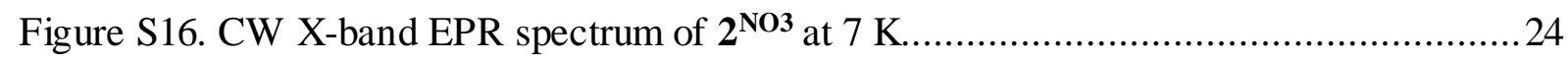

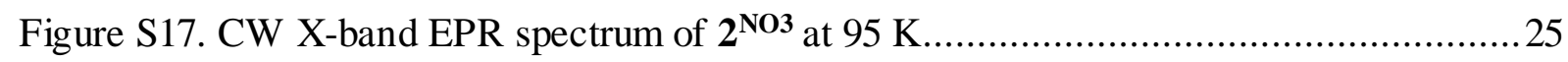

Figure S18. Temperature-dependent SQUID magnetization data of a powder sample of $\mathbf{2}^{\mathbf{O A c}}$

Figure S19. Temperature-dependent SQUID magnetization data of a powder sample of $2^{\text {NO3 }}$

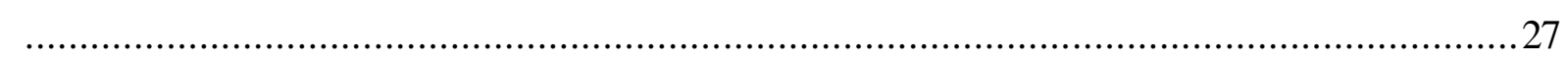

Figure S20: VT-VF SQUID magnetization data of a powder sample of $\mathbf{2}^{\mathrm{NO3}} \ldots \ldots \ldots \ldots \ldots \ldots \ldots . . . \ldots . \ldots . . . .28$

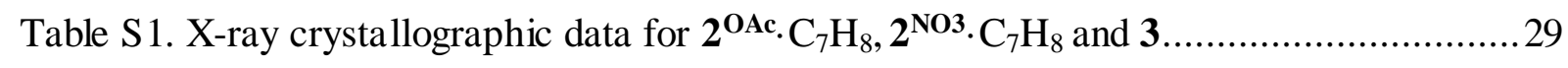

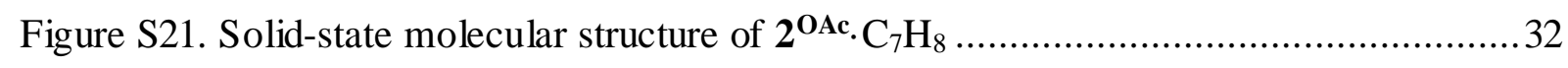

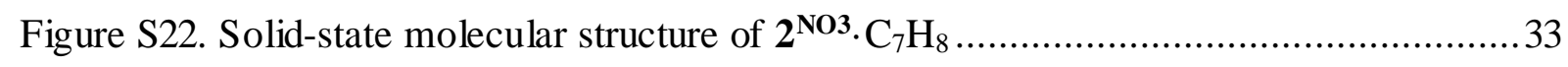

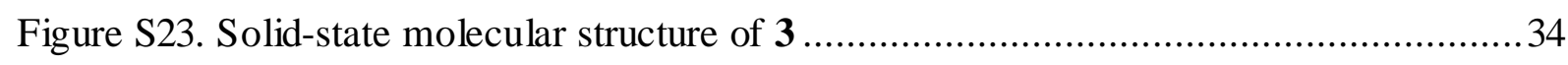

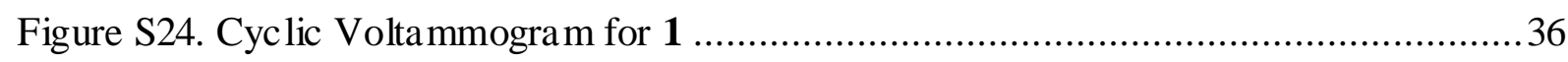

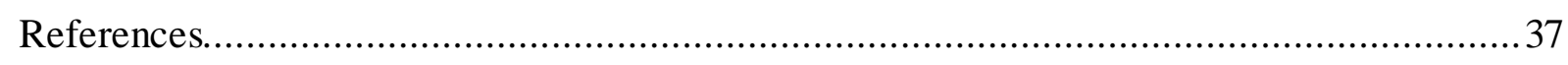




\section{Electron Paramagnetic Resonance (EPR) Spectroscopy details}

EPR spectra were recorded on a JEOL continuous wave spectrometer JES-FA200, equipped with an X-band Gunn diode oscillator bridge, a cylindric mode cavity, and a helium cryostat. The samples were measured in solution under nitrogen atmosphere in quartz glass EPR tubes at $95 \mathrm{~K}$ and $7 \mathrm{~K}$, respectively. The spectra shown were measured using the following parameters: microwave frequency $=8.959 \mathrm{GHz}$, modulation width 1.0 to $0.1 \mathrm{mT}$, microwave power $1.0 \mathrm{~mW}$, modulation frequency $100 \mathrm{kHz}$, time constant of $0.1 \mathrm{~s}$. Data analysis and simulation of the data was performed using the software "eview" and "esim", written by Dr. Eckhard Bill (MPI CEC, Mülheim/Ruhr), ${ }^{1,2}$ on the basis of a spin-Hamiltonian description of the electronic ground state:

$\widehat{H}=D\left(\hat{S}_{z}^{2}-\frac{1}{3} S(S+1)+\frac{E}{D}\left(\hat{S}_{x}^{2}-\hat{S}_{y}^{2}\right)\right)+\mu_{B} \underline{g} \vec{S}$.

Here, $S$ represents the total spin quantum number of the coupled system, $D$ and $E / D$ are the axial and rhombic zero-field parameters, respectively, and $\underline{g}$ is the g-matrix. Calculations are based on the $S=5 / 2$ routines developed by Gaffney and Silverstone. ${ }^{3}$ EPR line widths, $W$, are given in units of $\mathrm{cm}^{-1} / \mathrm{GHz}$ at full-width-half-maximum (FWHM). 


\section{${ }^{57}$ Fe Mössbauer Details}

Zero-field ${ }^{57} \mathrm{Fe}$ Mössbauer spectra were recorded on a WissEl Mössbauer spectrometer (MRG500) at a temperature of $77 \mathrm{~K}$ in constant acceleration mode. ${ }^{57} \mathrm{Co} / \mathrm{Rh}$ was used as $\gamma$-radiation source. WinNormos for Igor Pro software was used for the quantitative evaluation of the spectral parameters (least squares fitting to Lorentzian peaks). The minimum experimental line widths were $0.21 \mathrm{~mm} \mathrm{~s}^{-1}$ (full width at half maximum, FWHM). The temperature of the sample was controlled by a MBBC-HE0106 MÖSSBAUER He/ $\mathrm{N}_{2}$ cryostat within an accuracy of +/0.3 K. Least-square fitting of the Lorentzian signals was carried out with the "Mfit" software, developed by Dr. Eckhard Bill (MPI CEC, Mülheim/Ruhr). ${ }^{4,5}$ The isomer shifts were reported relative to $\alpha$-iron reference at $300 \mathrm{~K}$. 


\section{SQUID magnetization meas urement details}

Magnetism data of microcrystalline and powdered samples (10.0-25.0 mg), loaded within polycarbonate gel capsules, were collected on a Quantum Design MPMS-3 SQUID magnetometer. DC susceptibility was recorded in the temperature range of $2-300 \mathrm{~K}$ with an applied DC field of $1 \mathrm{~T}$, if not stated otherwise, or by means of field-dependent measurements in the temperature range of $2-150 \mathrm{~K}$ under $\mathrm{DC}$ magnetic fields of $0.1,1.0,3.0$, and $5.0 \mathrm{~T}$, respectively. Values of the magnetic susceptibility were corrected for core diamagnetism of the sample using tabulated Pascal's constants. ${ }^{6}$ For simulation and analysis of the data, the program “JulX2", written by Dr. Eckhard Bill (MPI CEC, Mülheim/Ruhr) was used.7 


\section{Crystallographic details}

Suitable crystals for analysis of complexes $2^{\mathbf{O A c}} \cdot \mathrm{C}_{7} \mathrm{H}_{8}, 2^{\mathrm{NO}} \cdot \mathrm{C}_{7} \mathrm{H}_{8}$, and $\mathbf{3}$ were mounted on the end of a Cryoloop coated in NVH oil and data collection was performed using a Bruker APEXII $\mathrm{CCD}$ area detector employing Mo Ka radiation (graphite monochromator) at a temperature of $100 \mathrm{~K}$. Rotation frames were integrated using SAINT, ${ }^{8}$ producing a listing of unaveraged $\mathrm{F}^{2}$ and $\left(\mathrm{F}^{2}\right)$ values which were then passed to the SHELXTL $^{9}$ program package for further processing and structure solution. The intensity data were corrected for Lorentz and polarization effects and for absorption using TWINABS ${ }^{10}$ or SADABS. ${ }^{11}$ The structures were solved by direct methods (SHELXS-97). ${ }^{12}$ Refinement was by full-matrix least-squares based on $\mathrm{F}^{2}$ using SHELXL-97. ${ }^{12}$ All reflections were used during refinement. Non-hydrogen atoms were refined anisotropically and hydrogen atoms were refined using a riding model. 


\section{Cyclic Voltamme try details}

Cyclic voltammetric measurements were performed using a $\mathrm{CH}$ Instruments 600e potentiostat with a PC unit controlled with CHI software (version 13.12). Experiments were performed in a

glovebox under an inert $\mathrm{N}_{2}$ atmosphere using platinum disks embedded in Kel-F thermoplastic, as the counter and working electrodes while the reference electrode. [TBA] $\left.\mathrm{PF}_{6}\right]$ was recrystallized 4 times from boiling ethanol, subsequent storage at $-20{ }^{\circ} \mathrm{C}$ under air and drying of the white crystals under dynamic vacuum (350 mtorr) for $14 \mathrm{~h}$ at $80{ }^{\circ} \mathrm{C}$ prior to electrochemical studies. Cyclic Voltammogram for $\mathbf{1}(0.1 \mathrm{mM}$ solution in DCM) were collected at $25{ }^{\circ} \mathrm{C}$ between scan rates of $25-500 \mathrm{mV} / \mathrm{s}$ with $[\mathrm{TBA}]\left[\mathrm{PF}_{6}\right]$ as the supporting electrolyte $(0.1$ M solution in DCM) and referenced against the $\mathrm{FeCp}_{2}{ }^{0 /+}$ couple. 


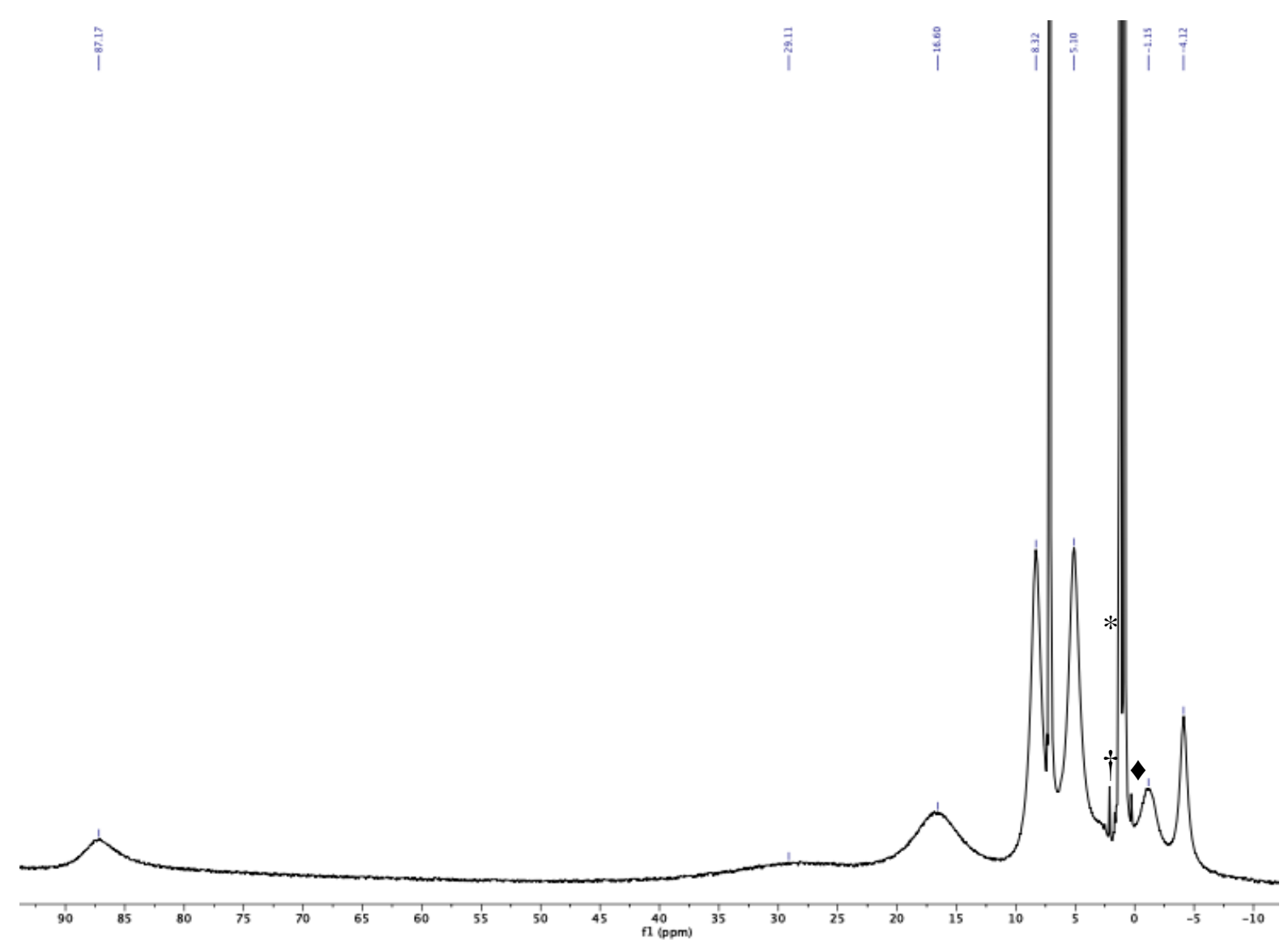

Figure S1. ${ }^{1} \mathrm{H}$ NMR spectrum of $2^{\mathbf{O A c}}$ in $\mathrm{C}_{6} \mathrm{D}_{6}$ at $25^{\circ} \mathrm{C}$. Rhombus ( $\bullet$ denotes the presence of residual silicone grease. Asterix $(*)$ denote the presence of residual $n$-pentane. Dagger $(\dagger)$ denotes the presence of residual toluene. 


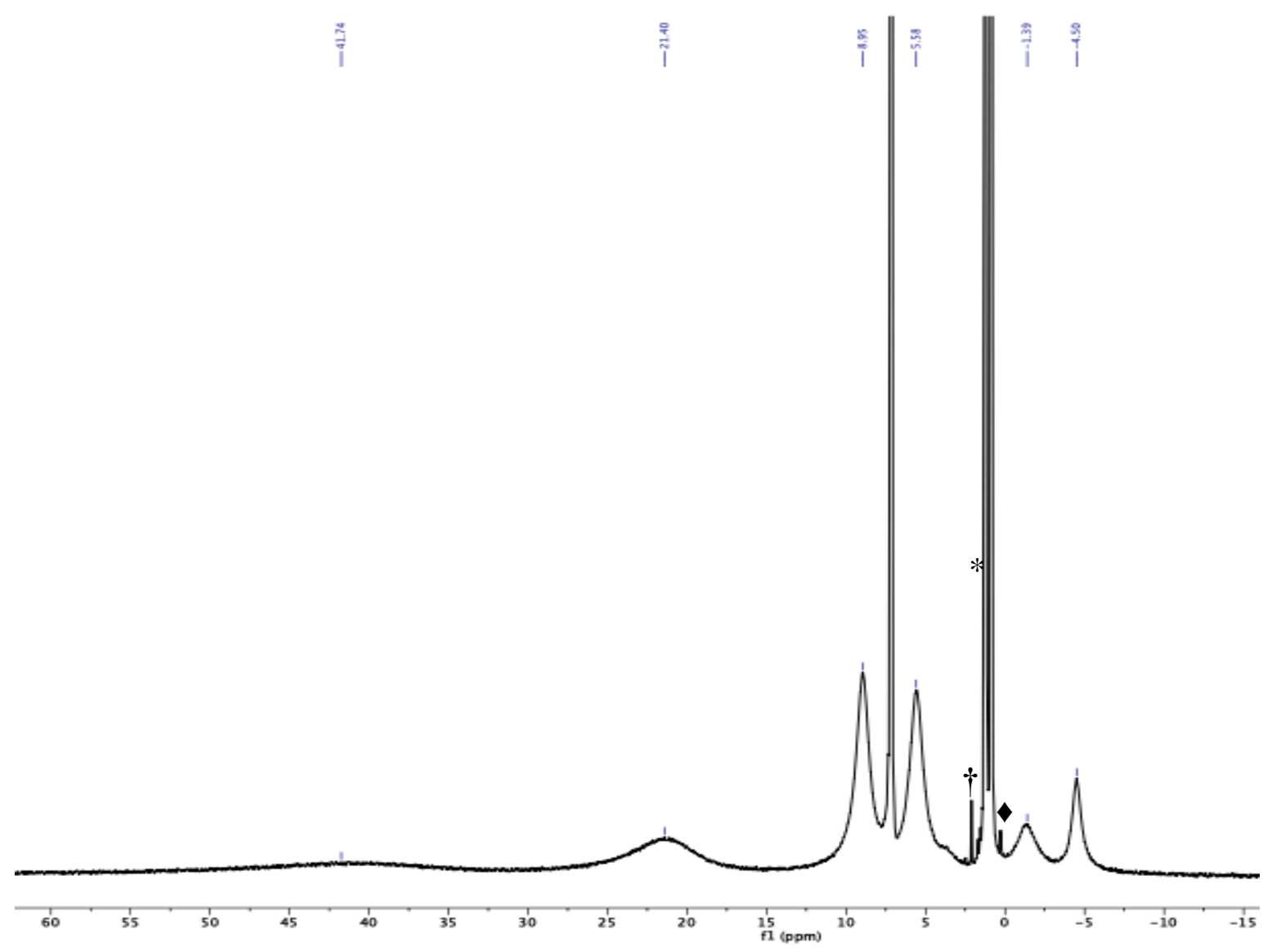

Figure S2. ${ }^{1} \mathrm{H}$ NMR spectrum of $2^{\mathrm{NO}_{3}}$ in $\mathrm{C}_{6} \mathrm{D}_{6}$ at $25{ }^{\circ} \mathrm{C}$. Rhombus $(\diamond)$ denotes the presence of residual silicone grease. Asterix $(*)$ denote the presence of residual $n$-pentane. Dagger $(\dagger)$ denotes the presence of residual toluene. 


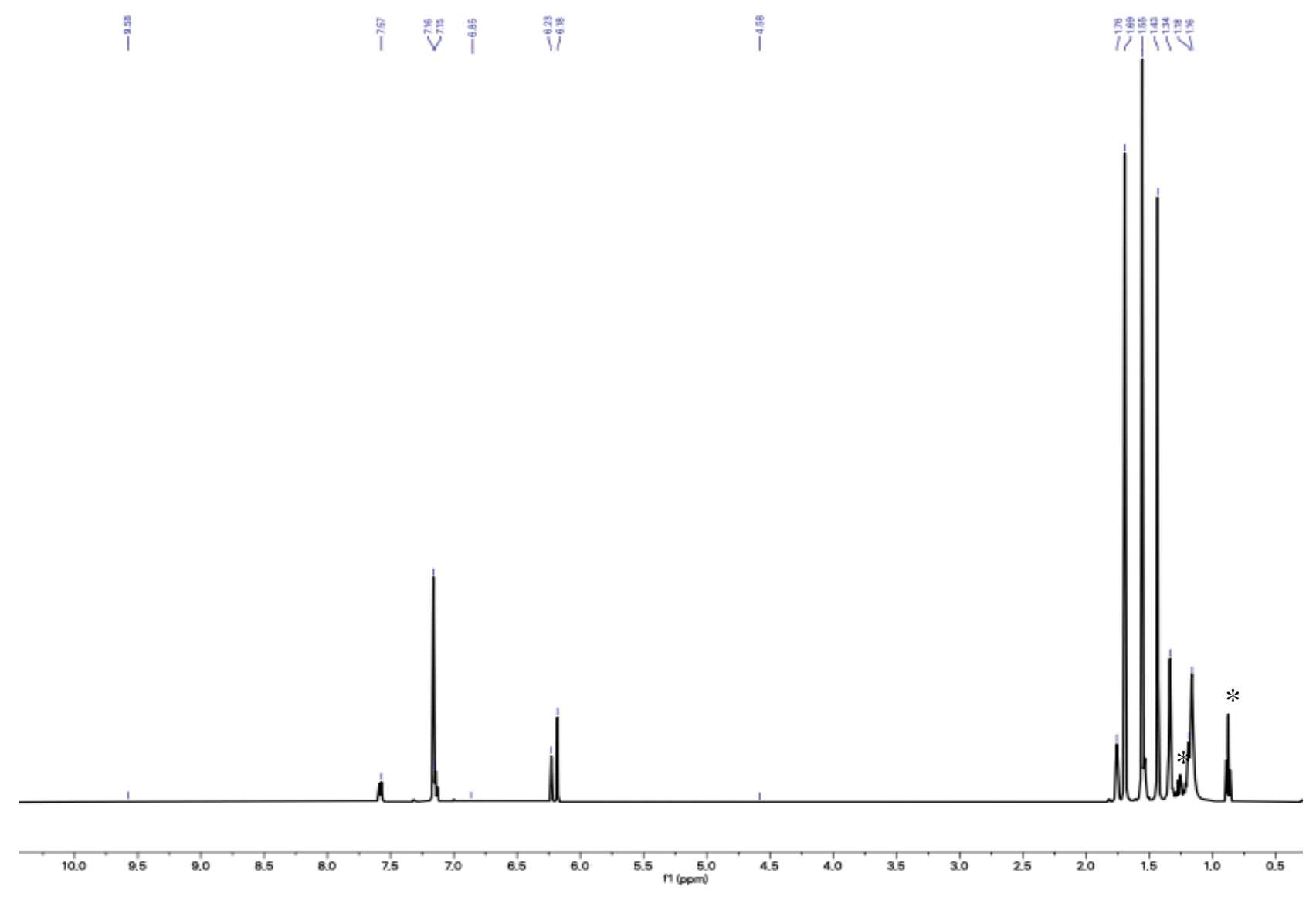

Figure S3. ${ }^{1} \mathrm{H}$ NMR spectrum of 3 in $\mathrm{C}_{6} \mathrm{D}_{6}$ at $25^{\circ} \mathrm{C}$. Asterix (*) denote the presence of residual $n$-hexane. 


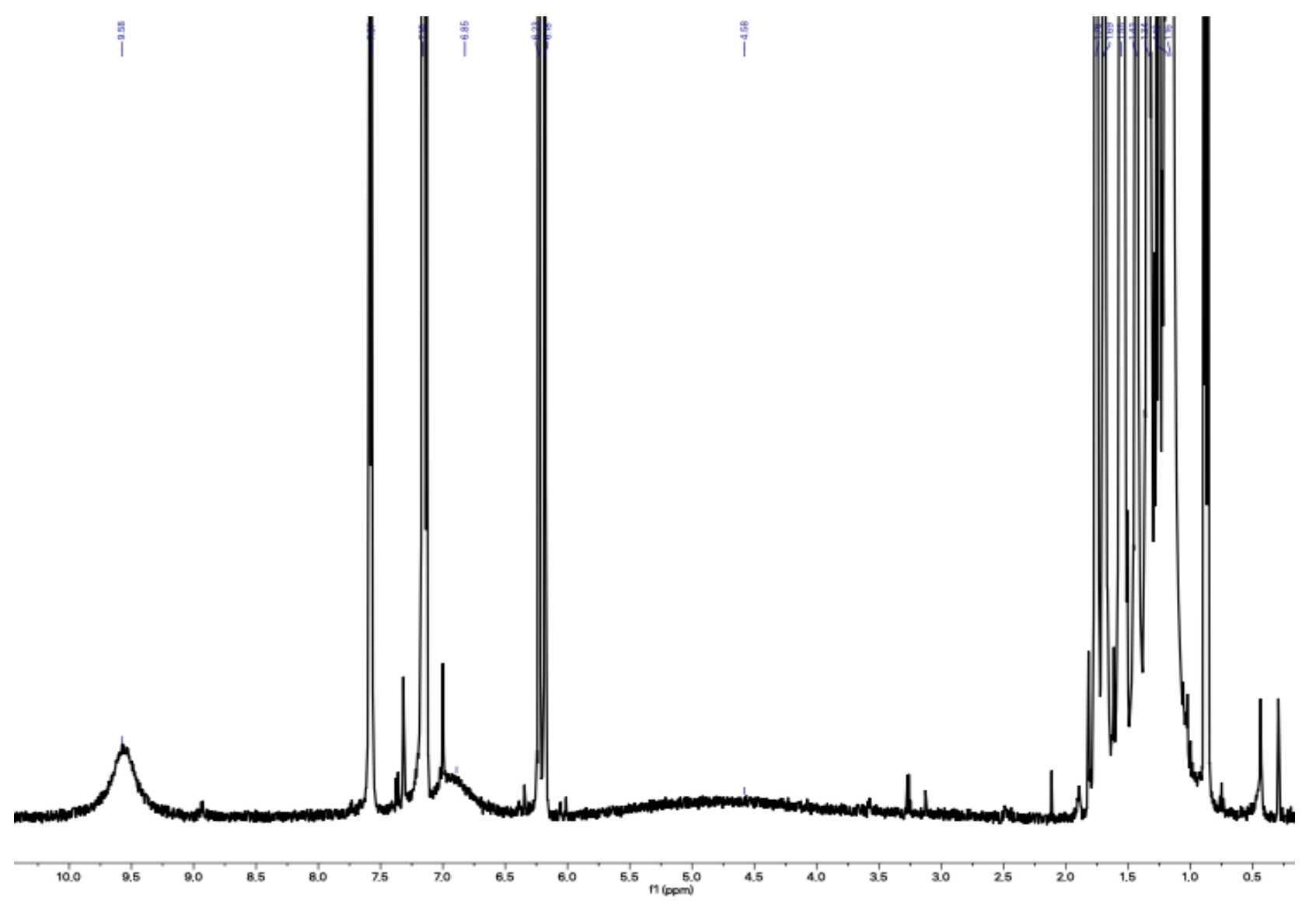

Figure S4. ${ }^{1} \mathrm{H}$ NMR spectrum of 3 in $\mathrm{C}_{6} \mathrm{D}_{6}$ at $25{ }^{\circ} \mathrm{C}$ with magnification of the pyrrole and adamantly $\mathrm{N}-H$ resonances. 


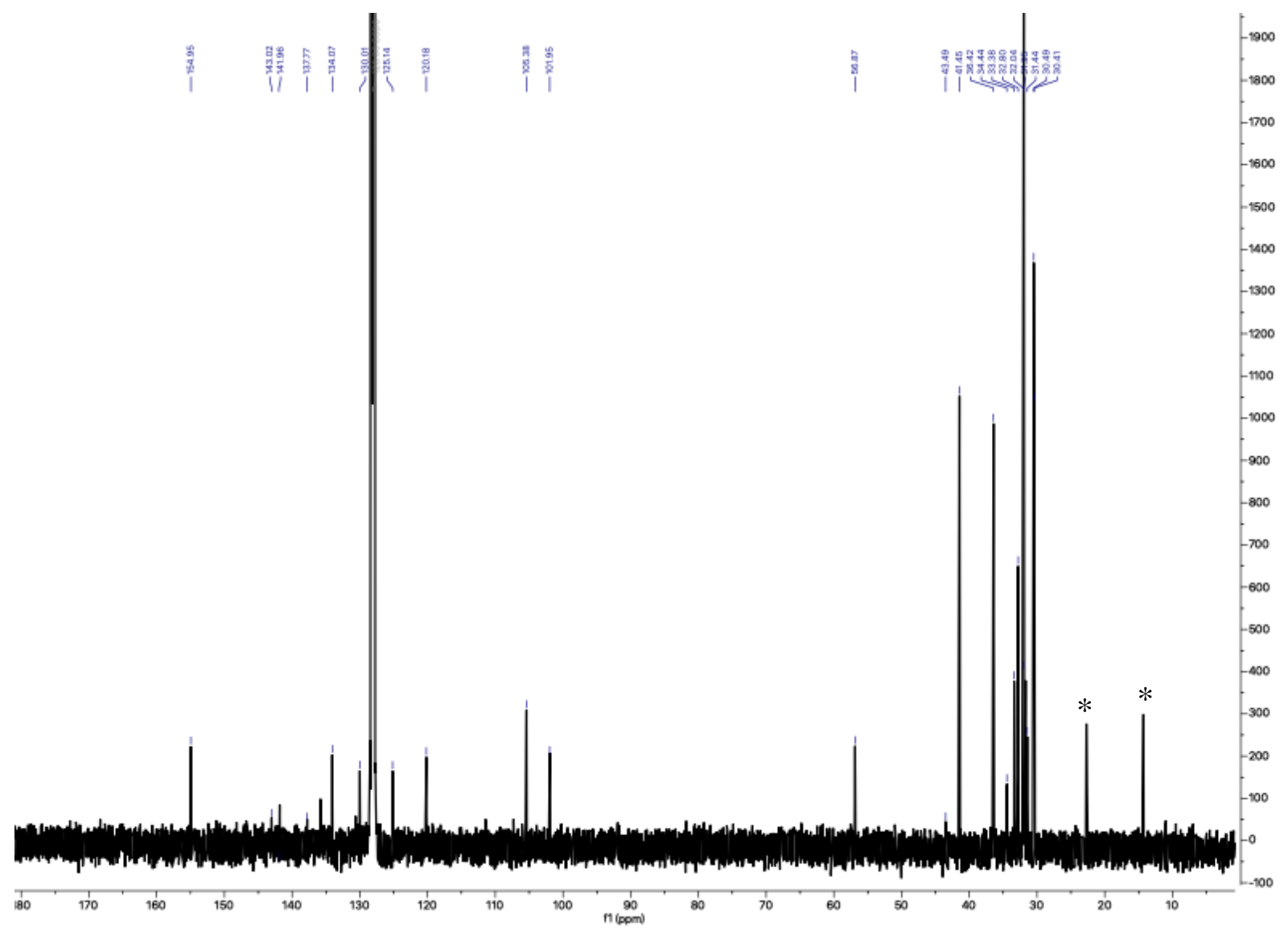

Figure S5. ${ }^{13} \mathrm{C}\left\{{ }^{1} \mathrm{H}\right\}$ NMR spectrum of 3 in $\mathrm{C}_{6} \mathrm{D}_{6}$ at $25{ }^{\circ} \mathrm{C}$. Asterix $(*)$ denote the presence of residual $n$-hexane. 


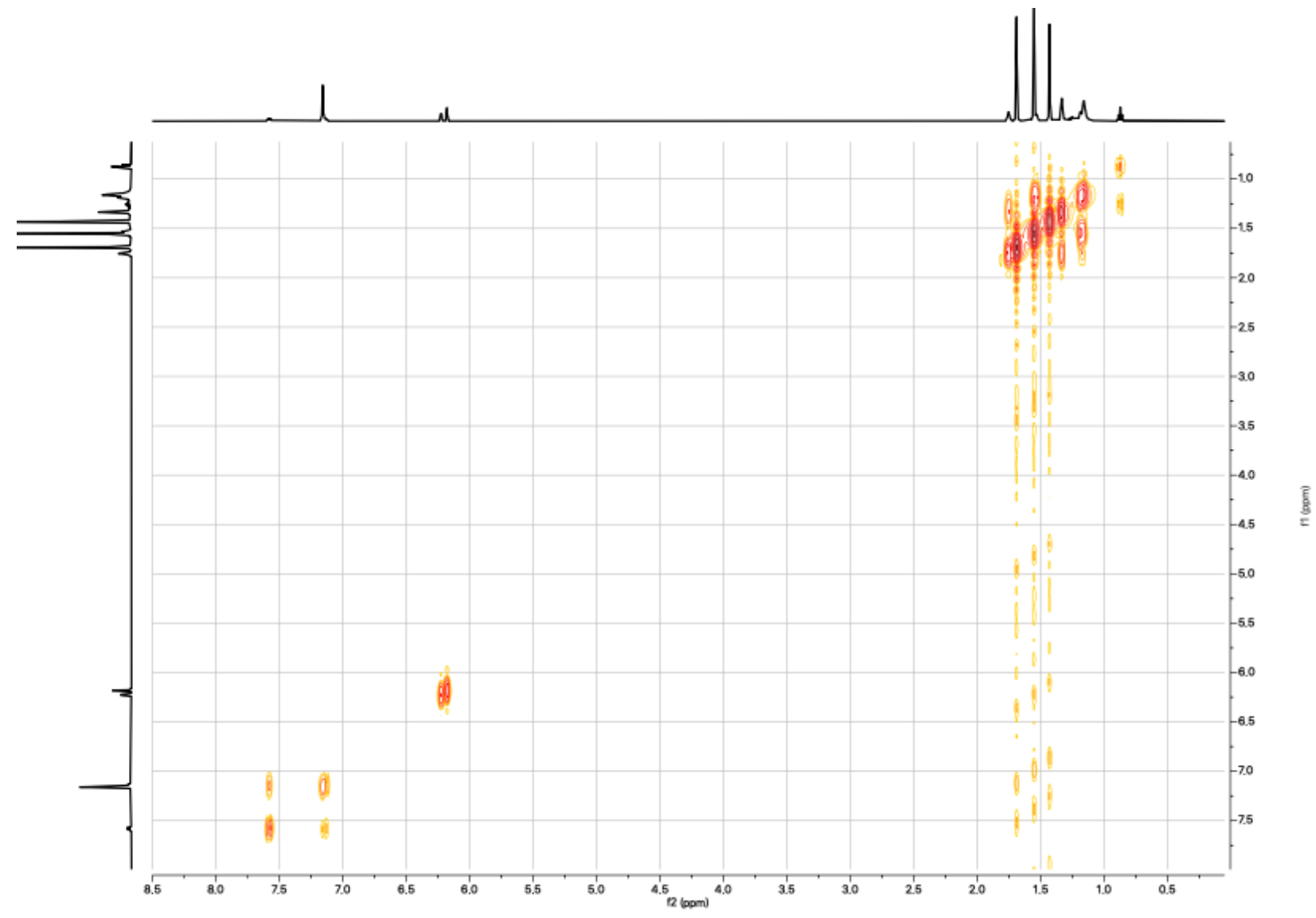

Figure S6. ${ }^{1} \mathrm{H}-{ }^{1} \mathrm{H}$ COSY NMR spectrum of 3 in $\mathrm{C}_{6} \mathrm{D}_{6}$ at $25{ }^{\circ} \mathrm{C}$. 


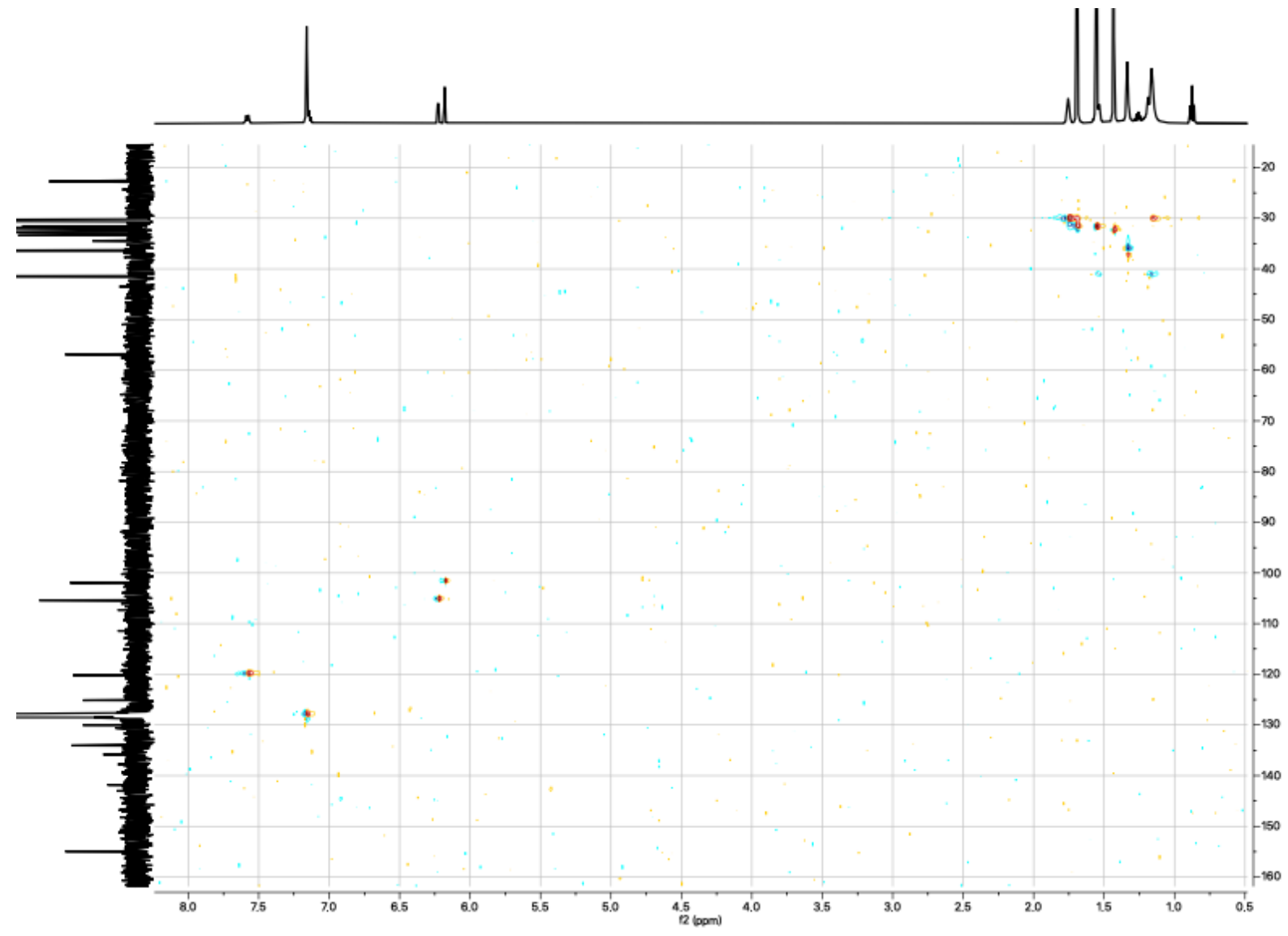

Figure S7. ${ }^{1} \mathrm{H}-{ }^{13} \mathrm{C}$ HSQC NMR spectrum of 3 in $\mathrm{C}_{6} \mathrm{D}_{6}$ at $25{ }^{\circ} \mathrm{C}$. 


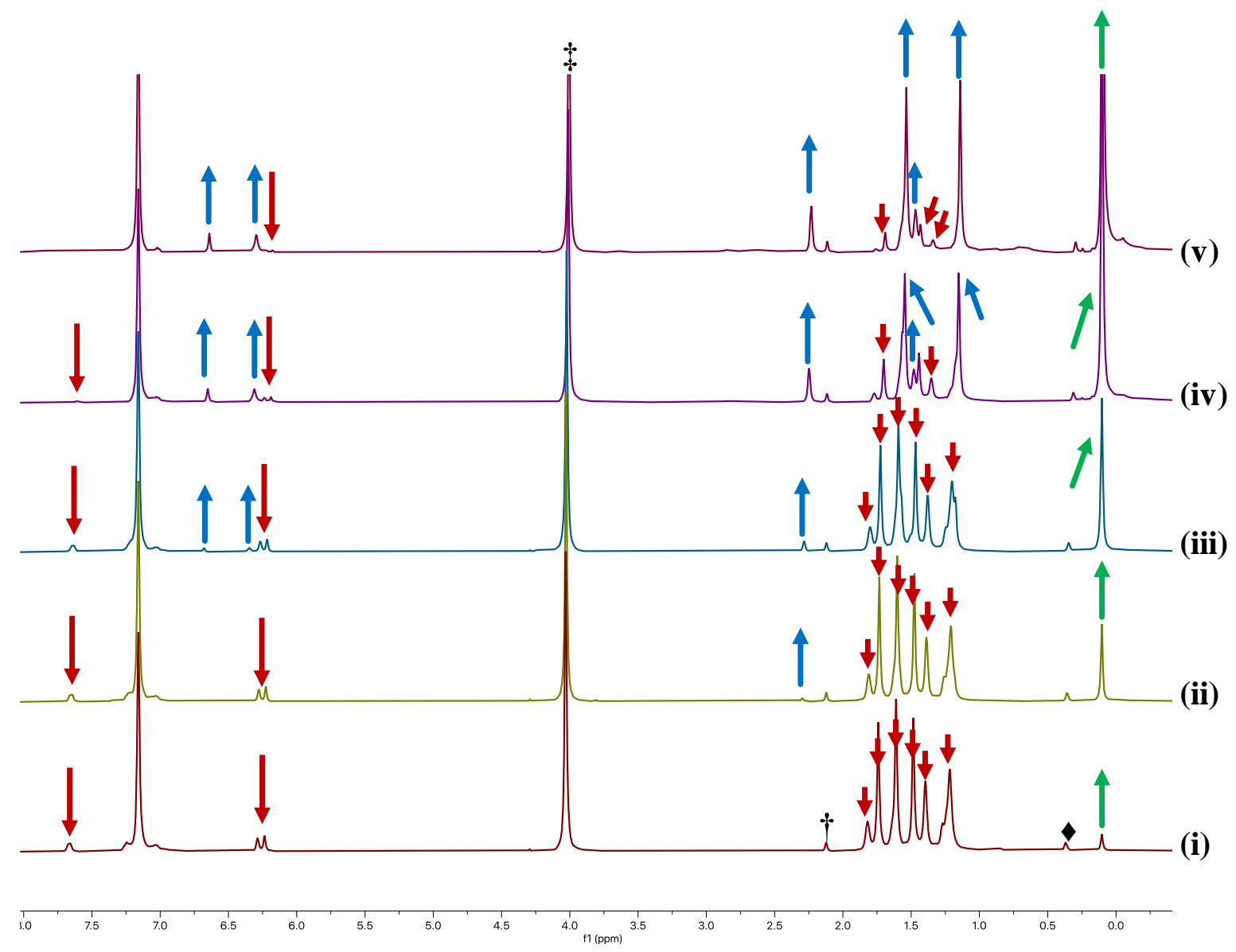

Figure S8. Stacked ${ }^{1} \mathrm{H}$ NMR spectra of the thermal conversion of $\left[\mathrm{Fe}\left(\mathrm{N}\left(\mathrm{SiMe}_{3}\right)_{2}\right)_{2}\right]$ and $\mathbf{3}(\downarrow)$ to $\mathbf{1}(\uparrow)$ and $\mathrm{HN}\left(\mathrm{SiMe}_{3}\right)_{2}(\uparrow)$ in $\mathrm{C}_{6} \mathrm{D}_{6}$ at $25{ }^{\circ} \mathrm{C}$. Spectrum recorded after intervals of $20 \mathrm{~min}(\mathbf{i})$, $2 \mathrm{~h}$ (ii), $4 \mathrm{~h}$ (iii), $6 \mathrm{~h}$ (iv), and $24 \mathrm{~h}(\mathbf{v})$. Double dagger ( $\$)$ denotes the presence of $\mathrm{FeCp}_{2}$ as an internal standard. Rhombus $(\diamond)$ denotes the presence of residual silicone grease. Dagger $(\dagger)$ denotes the presence of residual toluene. 


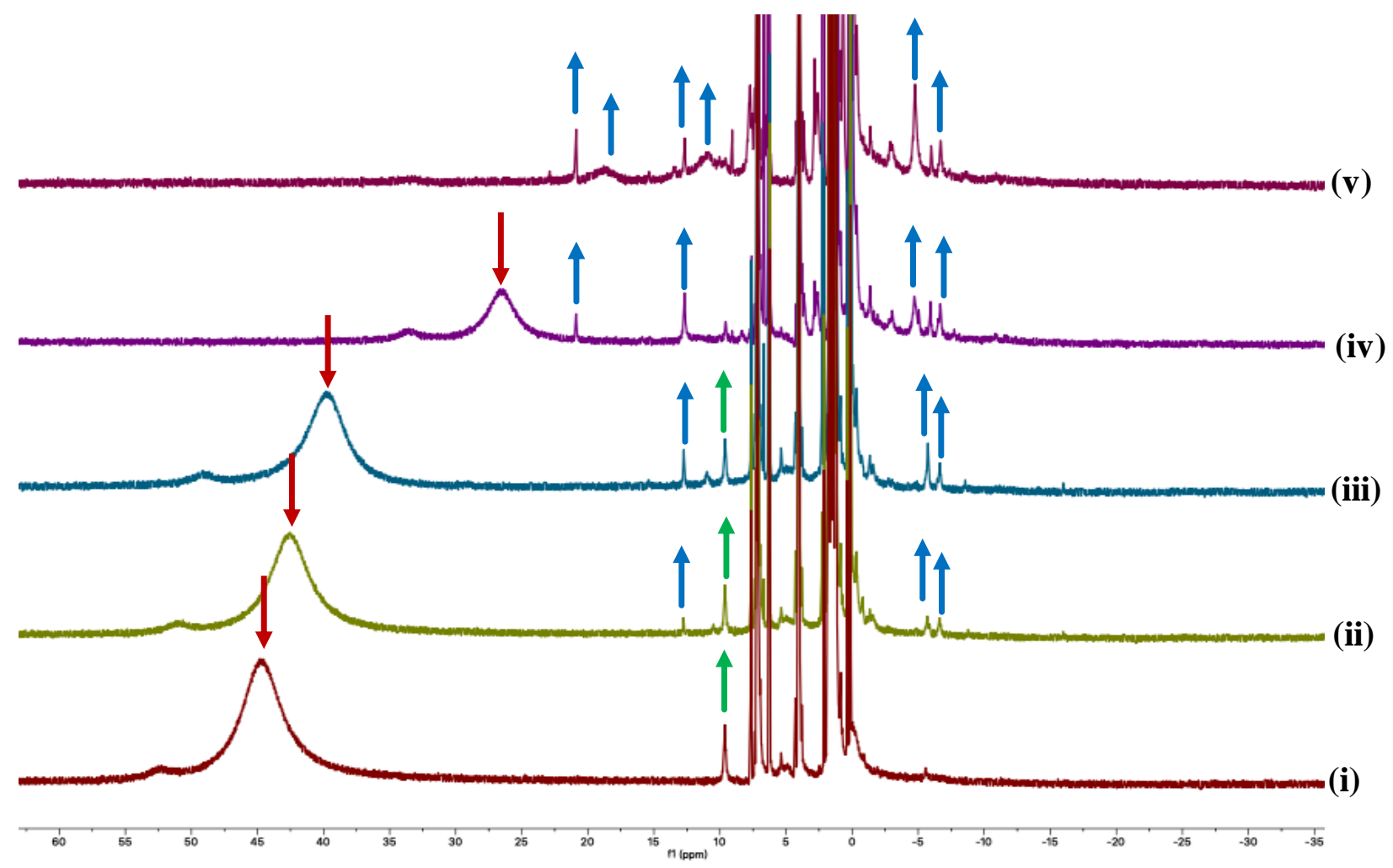

Figure S9. Stacked ${ }^{1} \mathrm{H}$ NMR spectra of the thermal conversion of $\mathrm{Fe}\left(\mathrm{N}\left(\mathrm{SiMe}_{3}\right)_{2}(\downarrow)\right.$ and $\mathbf{3}$ to paramagnetic species $(\uparrow)$ and $(\uparrow)$ in $\mathrm{C}_{6} \mathrm{D}_{6}$ at $25^{\circ} \mathrm{C}$. Spectrum recorded after intervals of $20 \mathrm{~min}$ (i), $2 \mathrm{~h}$ (ii), $4 \mathrm{~h}$ (iii), $6 \mathrm{~h}$ (iv), and $24 \mathrm{~h}(\mathbf{v})$. 

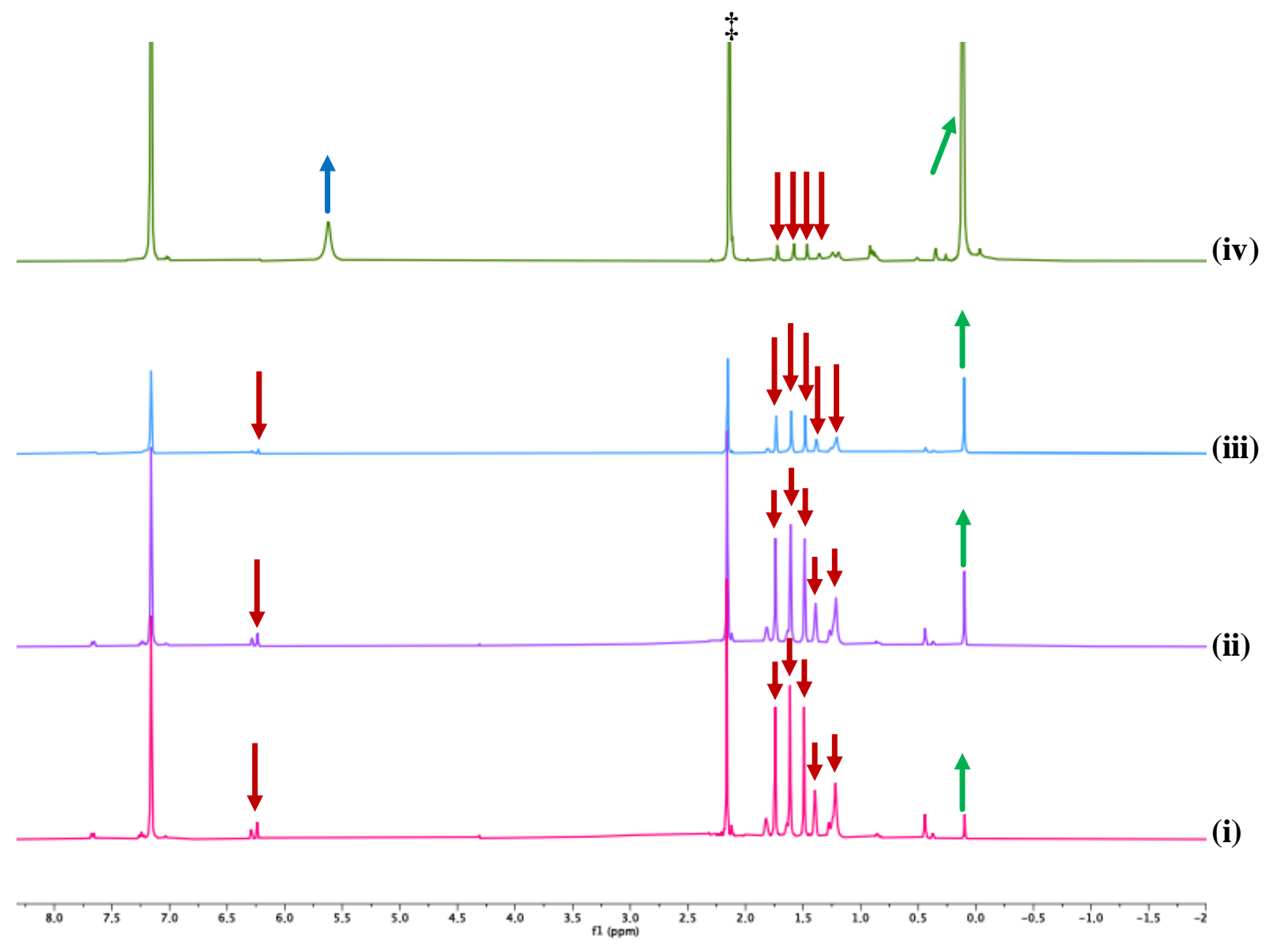

Figure S10. Stacked ${ }^{1} \mathrm{H}$ NMR spectra of the thermal conversion of $\left[\mathrm{Co}\left(\mathrm{N}\left(\mathrm{SiMe}_{3}\right)_{2}\right)_{2}\right]$ and $\mathbf{3}(\downarrow)$ to $4(\uparrow)$ and $\mathrm{HN}\left(\mathrm{SiMe}_{3}\right)_{2}(\uparrow)$ in $\mathrm{C}_{6} \mathrm{D}_{6}$ at $25{ }^{\circ} \mathrm{C}$. Spectrum recorded after intervals of $20 \mathrm{~min}(\mathbf{i})$, $2 \mathrm{~h}$ (ii), $4 \mathrm{~h}$ (iii), $6 \mathrm{~h}$ (iv), and $24 \mathrm{~h}(\mathbf{v})$. Double dagger ( $\$$ ) denotes the presence of $\mathrm{C}_{6} \mathrm{Me}_{6}$ as an internal standard. 


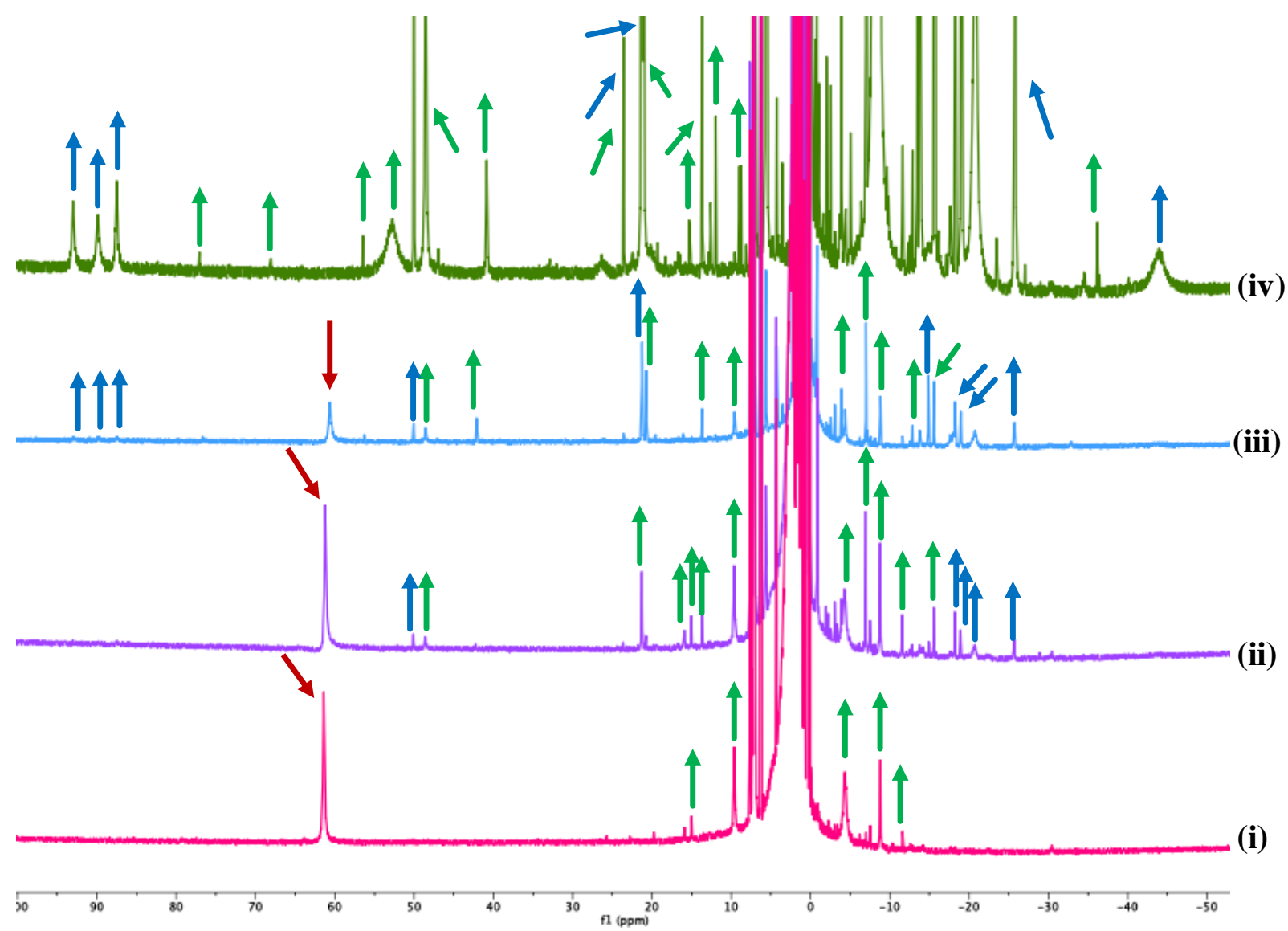

Figure S11. Stacked ${ }^{1} \mathrm{H}$ NMR stacked spectra of the thermal conversion of $\left[\mathrm{Co}\left(\mathrm{N}\left(\mathrm{SiMe}_{3}\right)_{2}\right)_{2}\right]$

$(\downarrow)$ and 3 to 4 ( $\uparrow)$ and paramagnetic species $(\uparrow)$ in $\mathrm{C}_{6} \mathrm{D}_{6}$ at $25^{\circ} \mathrm{C}$. Spectrum recorded after 20 min (i), $2 \mathrm{~h}$ (ii), $4 \mathrm{~h}$ (iii), $6 \mathrm{~h}$ (iv), and $24 \mathrm{~h} \mathrm{(v).}$ 


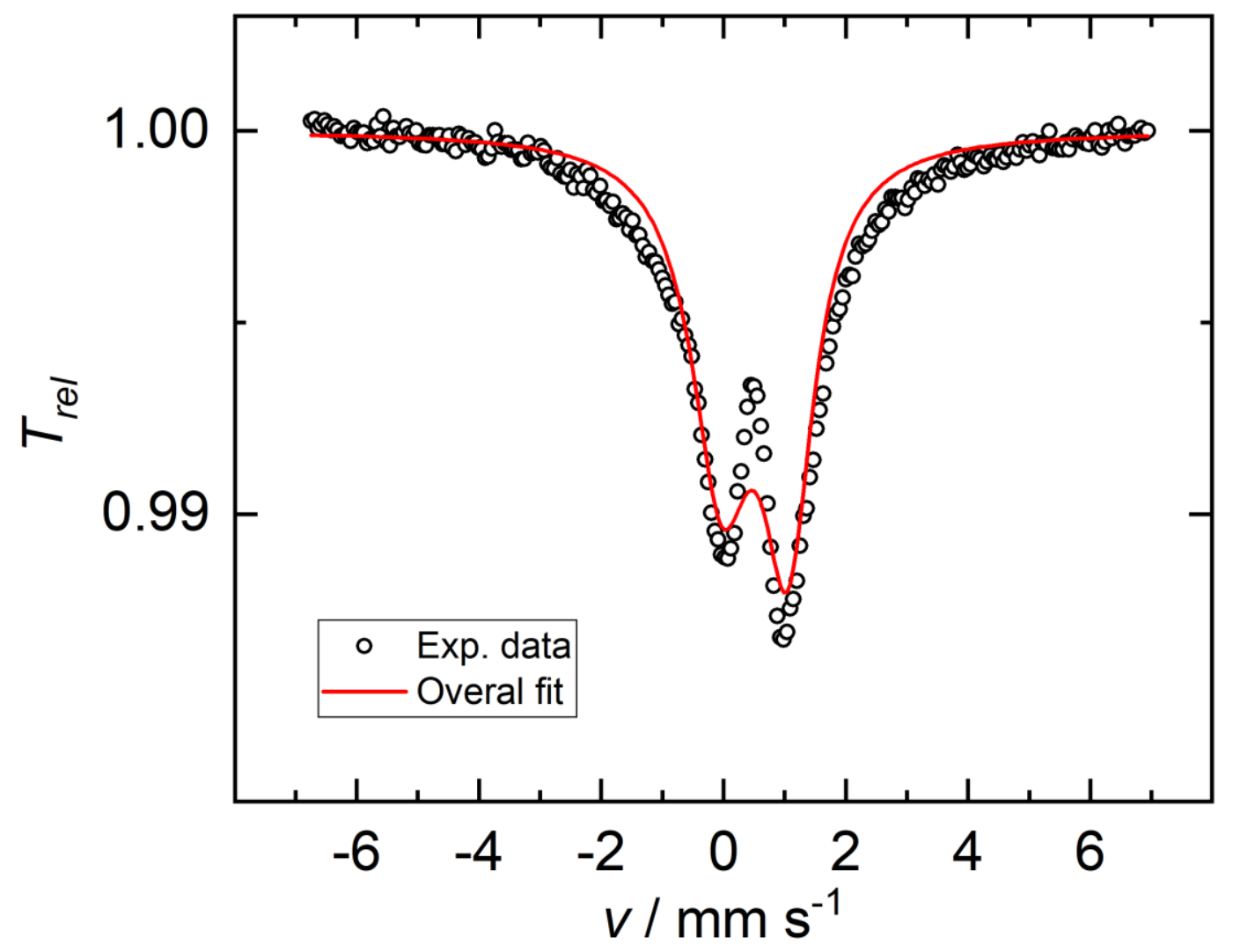

\begin{tabular}{|l|c|}
\hline $\mathbf{2}^{\mathrm{OAc}}$ & Species 1 \\
\hline Type & doublet \\
$\delta\left(\mathrm{mm} \mathrm{s}^{-1}\right)$ & 0.51 \\
$\Delta \mathrm{E}_{\mathrm{Q}}\left(\mathrm{mm} \mathrm{s}^{-1}\right)$ & 1.08 \\
$\Gamma_{\mathrm{FWHM}}\left(\mathrm{mm} \mathrm{s}^{-1}\right)$ & 1.20 \\
$\mathrm{w} 2 / 1$ & 0.85 \\
\hline
\end{tabular}

Figure S12. Zero-field ${ }^{57} \mathrm{Fe}$ Mössbauer spectrum of $\mathbf{2}^{\mathbf{0 A c}}$ recorded at $77 \mathrm{~K} . T_{\text {rel }}=$ relative transmission. Open symbols represent experimental data and solid lines represent fitted data. 


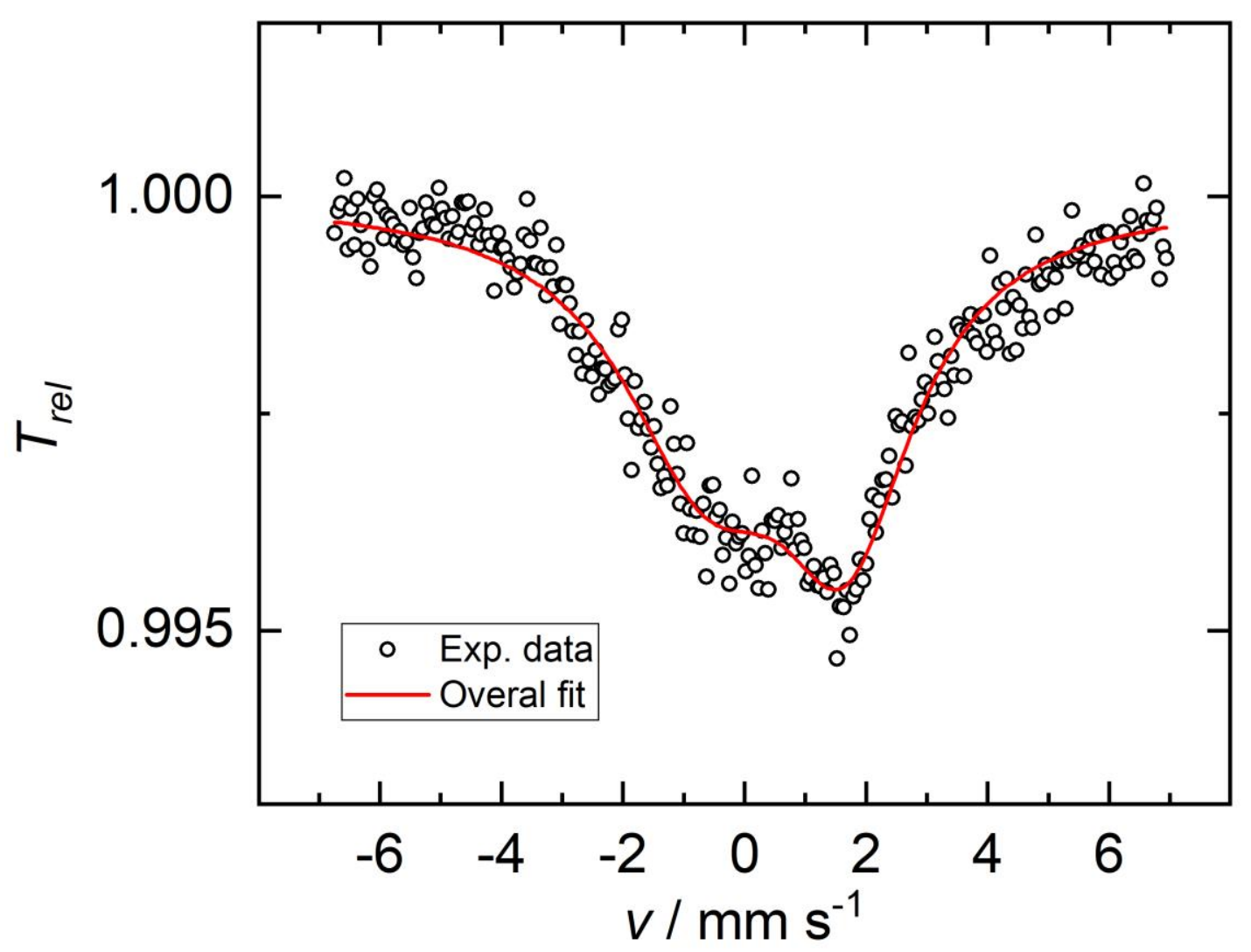

\begin{tabular}{|l|c|}
\hline $\mathbf{2}^{\mathrm{NO3}}$ & Species 1 \\
\hline Type & 0.52 \\
$\delta\left(\mathrm{mm} \mathrm{s}^{-1}\right)$ & 2.30 \\
$\Delta \mathrm{E}_{\mathrm{Q}}\left(\mathrm{mm} \mathrm{s}^{-1}\right)$ & 3.44 \\
$\Gamma_{\mathrm{FWHM}}\left(\mathrm{mm} \mathrm{s}^{-1}\right)$ & 0.80 \\
$\mathrm{w} 2 / 1$ & \\
\hline
\end{tabular}

Figure S13. Zero-field ${ }^{57} \mathrm{Fe}$ Mössbauer spectrum of $2^{\mathrm{NO3}}$ recorded at $77 \mathrm{~K} . T_{\text {rel }}=$ relative transmission. Open symbols represent experimental data and solid lines represent fitted data. 


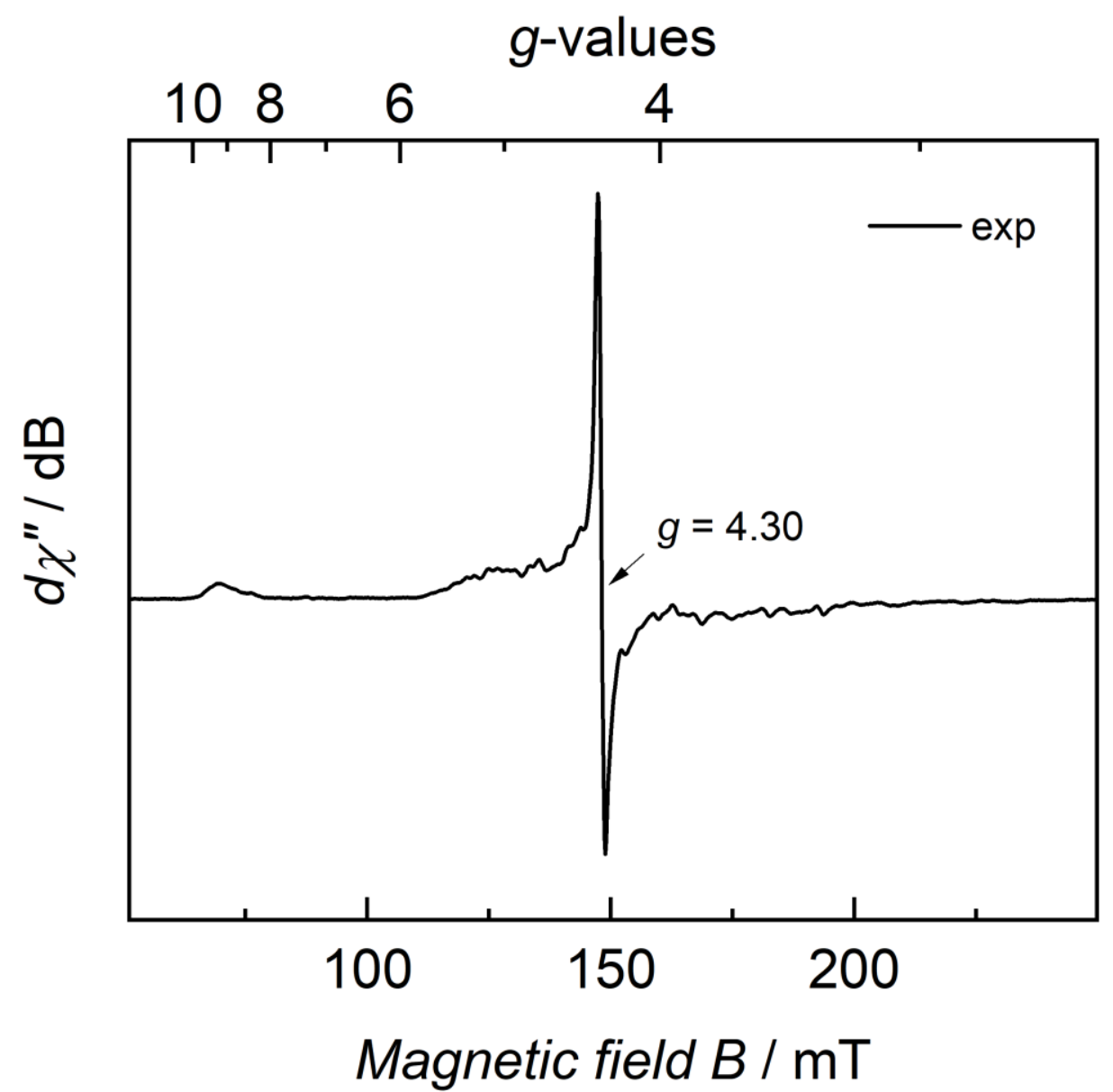

Figure S14. CW X-band EPR spectrum of $2^{\mathbf{O A c}}$ as a $1 \mathrm{mM}$ solution in toluene at $7 \mathrm{~K}$ (black trace). Experimental conditions: microwave frequency $v=8.959 \mathrm{GHz}$, modulation width $=$ $0.500 \mathrm{mT}$, microwave power $=1.0 \mathrm{~mW}$, modulation frequency $=100 \mathrm{kHz}$, time constant $=0.1$ s. 


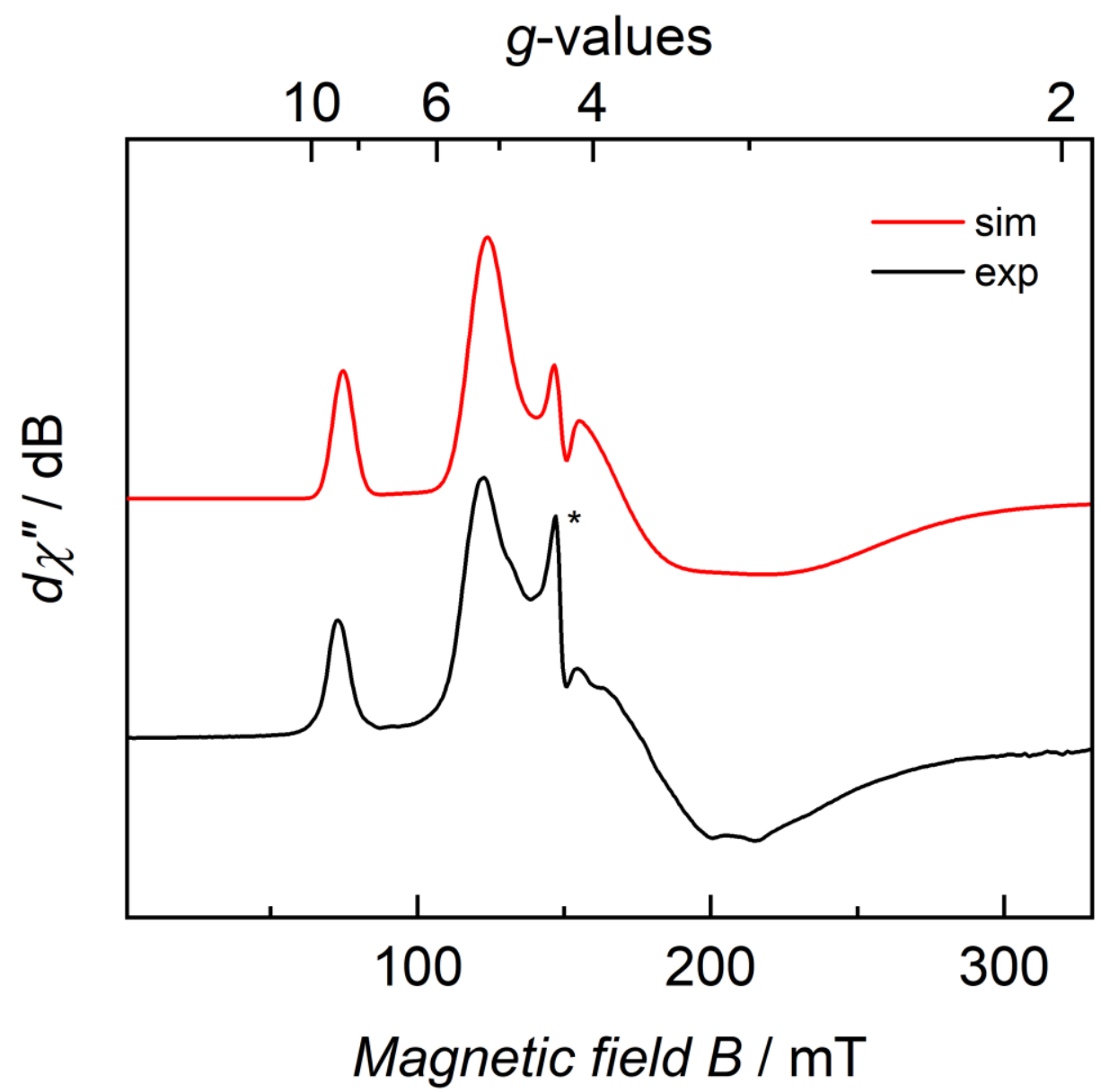

Figure S15. CW X-band EPR spectrum of $\mathbf{2}^{\text {OAc }}$ recorded as a $1 \mathrm{mM}$ solution in toluene at $95 \mathrm{~K}$ (black trace) and its simulation (red trace). Experimental conditions: microwave frequency $v=8.959 \mathrm{GHz}$, modulation $\quad$ width $=1.0 \mathrm{mT}$, microwave power $=1.0 \mathrm{~mW}$, modulation frequency $=100 \mathrm{kHz}$, time constant $=0.1 \mathrm{~s}$. Simulation parameters: effective spin $S=5 / 2$, $|D|=0.59 \mathrm{~cm}^{-1}, \quad E / D=0.16, \quad g$-values: $g_{1}=2.33, \quad g_{2}=1.97 \quad$ and $g_{3}=1.95 ; \quad$ linewidths : $W_{\text {FWHM,freq }}=28.4 \cdot 10^{-4} \mathrm{~cm}^{-1} / \mathrm{GHz}$. Gaussian distribution of $\mathrm{E} / \mathrm{D}$ with $\sigma(\mathrm{E} / \mathrm{D})=0.070$. The spectrum shares an additional feature $(*)$, centered at $g_{\text {iso }}=4.30$, which is likely due to a minor unknown Fe impurity (\#). 


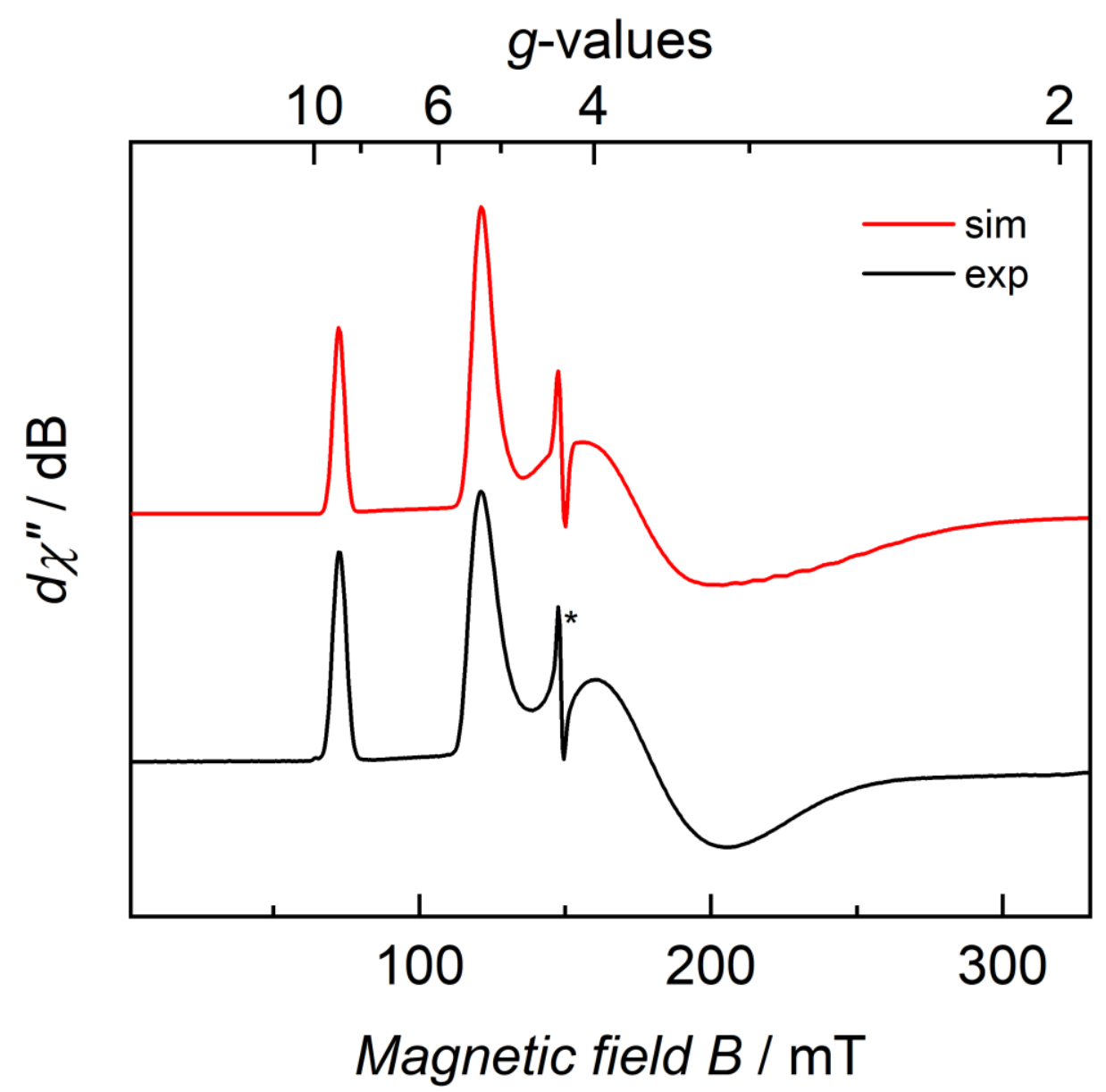

Figure S16. CW X-band EPR spectrum of $2^{\mathrm{NO3}}$ recorded as a $1 \mathrm{mM}$ solution in toluene at $7 \mathrm{~K}$ (black trace) and its simulation (red trace). Experimental conditions: microwave frequency $v=8.959 \mathrm{GHz}, \quad$ modulation $\quad$ width $=1.0 \mathrm{mT}, \quad$ microwave $\quad$ power $=1.0 \mathrm{~mW}, \quad$ modulation frequency $=100 \mathrm{kHz}$, time constant $=0.1$ s. Simulation parameters: effective spin $S=5 / 2$, $|D|=0.59 \mathrm{~cm}^{-1}, \quad E / D=0.15, \quad g$-values: $\quad g_{1}=2.33, \quad g_{2}=2.05 \quad$ and $\quad g_{3}=1.97 ; \quad$ linewidths : $W_{\mathrm{FWHM}, \text { freq }}=10.4 \cdot 10^{-4} \mathrm{~cm}^{-1} / \mathrm{GHz}$. Gaussian distribution of $\mathrm{E} / \mathrm{D}$ with $\sigma(\mathrm{E} / \mathrm{D})=0.071$. The spectrum shares an additional feature $(*)$, centered at $g_{\text {iso }}=4.30$, which is likely due to a minor unknown Fe impurity (\#). 


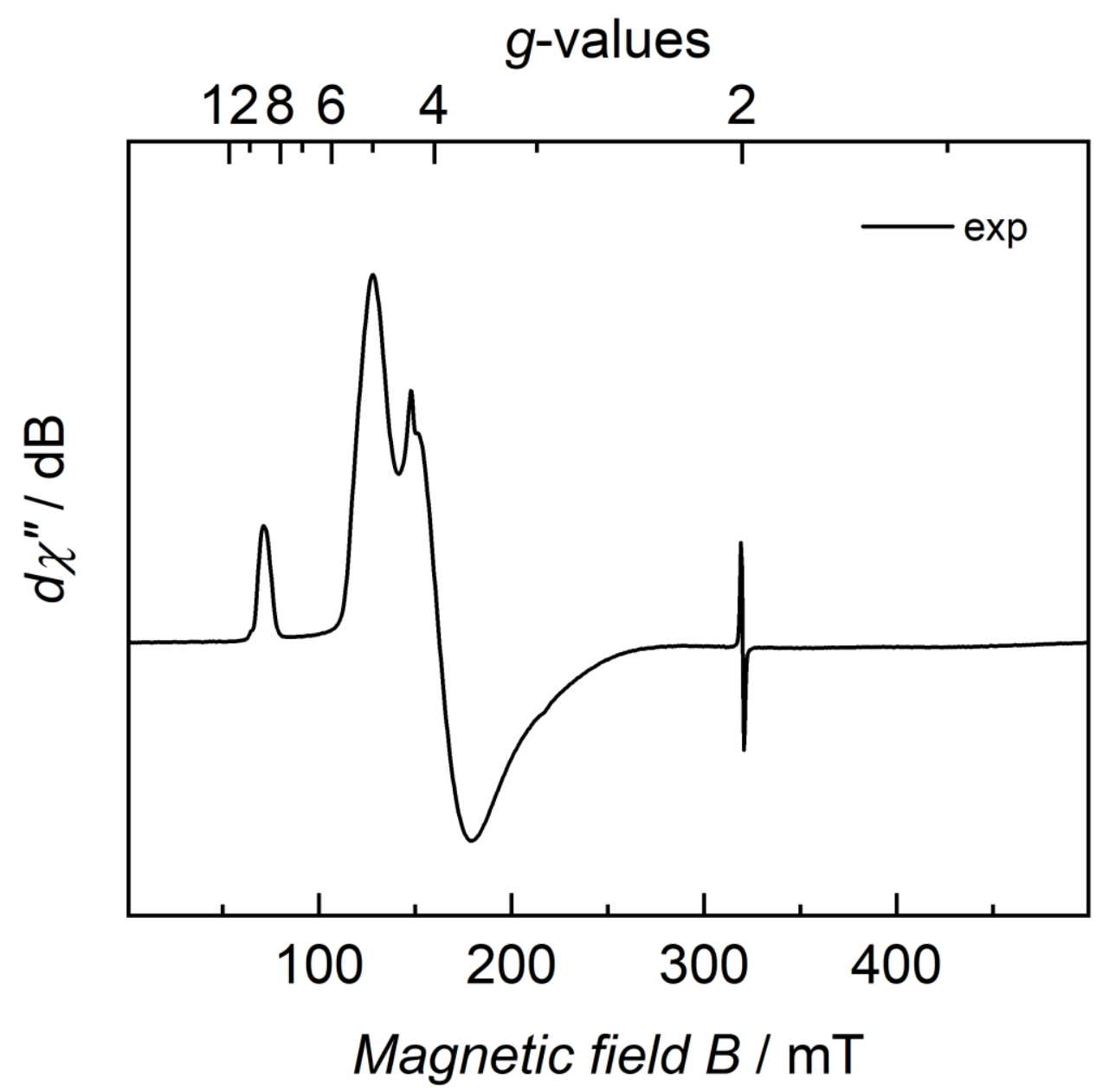

Figure S17. CW X-band EPR spectrum of $2^{\mathrm{NO3}}$ as a $1 \mathrm{mM}$ solution in toluene at $95 \mathrm{~K}$ (black trace). Experimental conditions: microwave frequency $v=8.959 \mathrm{GHz}$, modulation width $=0.250 \mathrm{mT}$, microwave power $=1.0 \mathrm{~mW}$, modulation frequency $=100 \mathrm{kHz}$, time constant $=0.1 \mathrm{~s}$. 


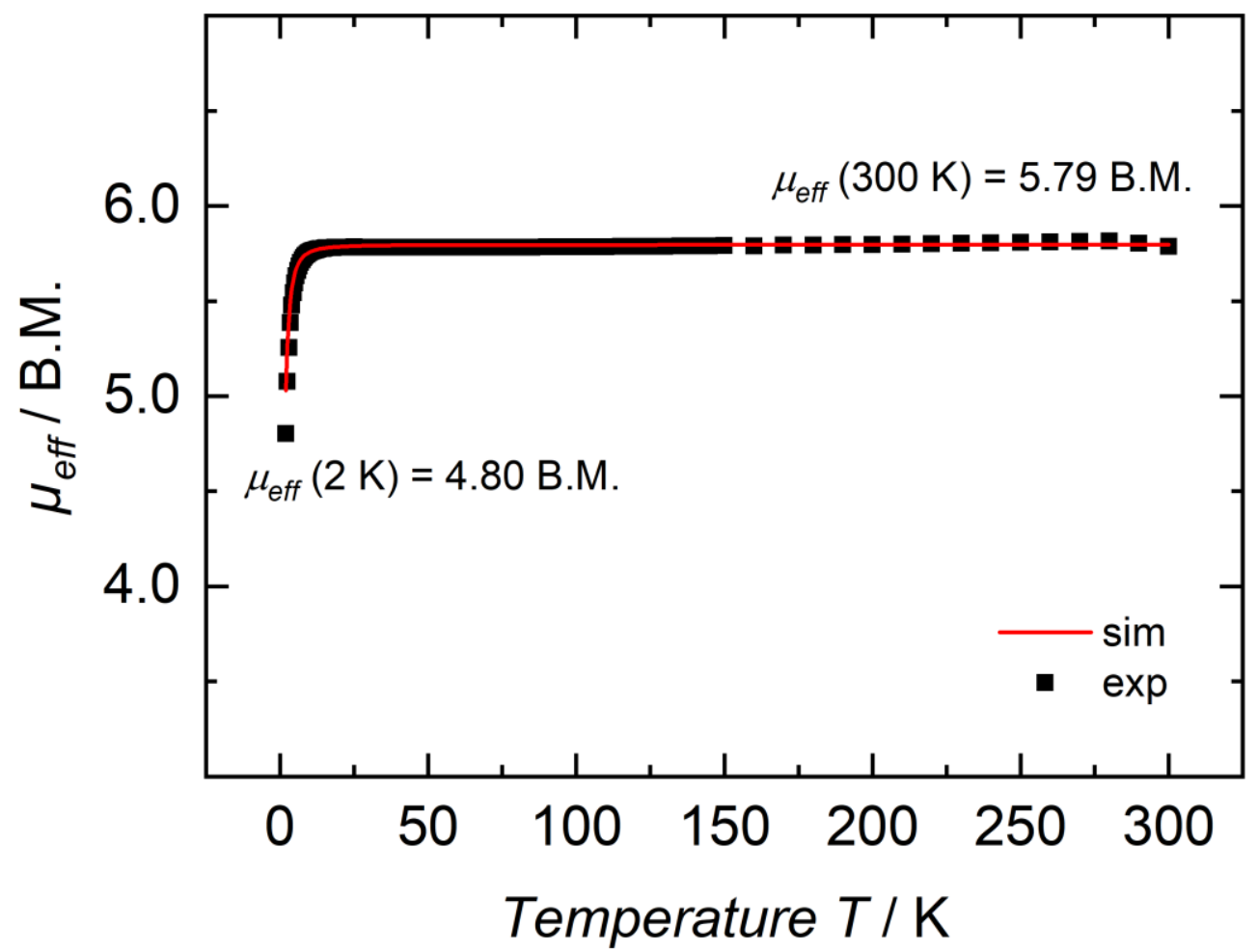

Figure S18. Temperature-dependent SQUID magnetization data of a powder sample of $\mathbf{2}^{\text {OAc }}$ (black squares) and its simulation (red trace), recorded with an applied magnetic field of $1 \mathrm{~T}$. Simulation parameters: $S=2.5$, TIP $=650 \cdot 10^{-6} \mathrm{emu},|D|=0.59 \mathrm{~cm}^{-1}, E / D=0.15, g_{\text {avg }}=1.96$. 


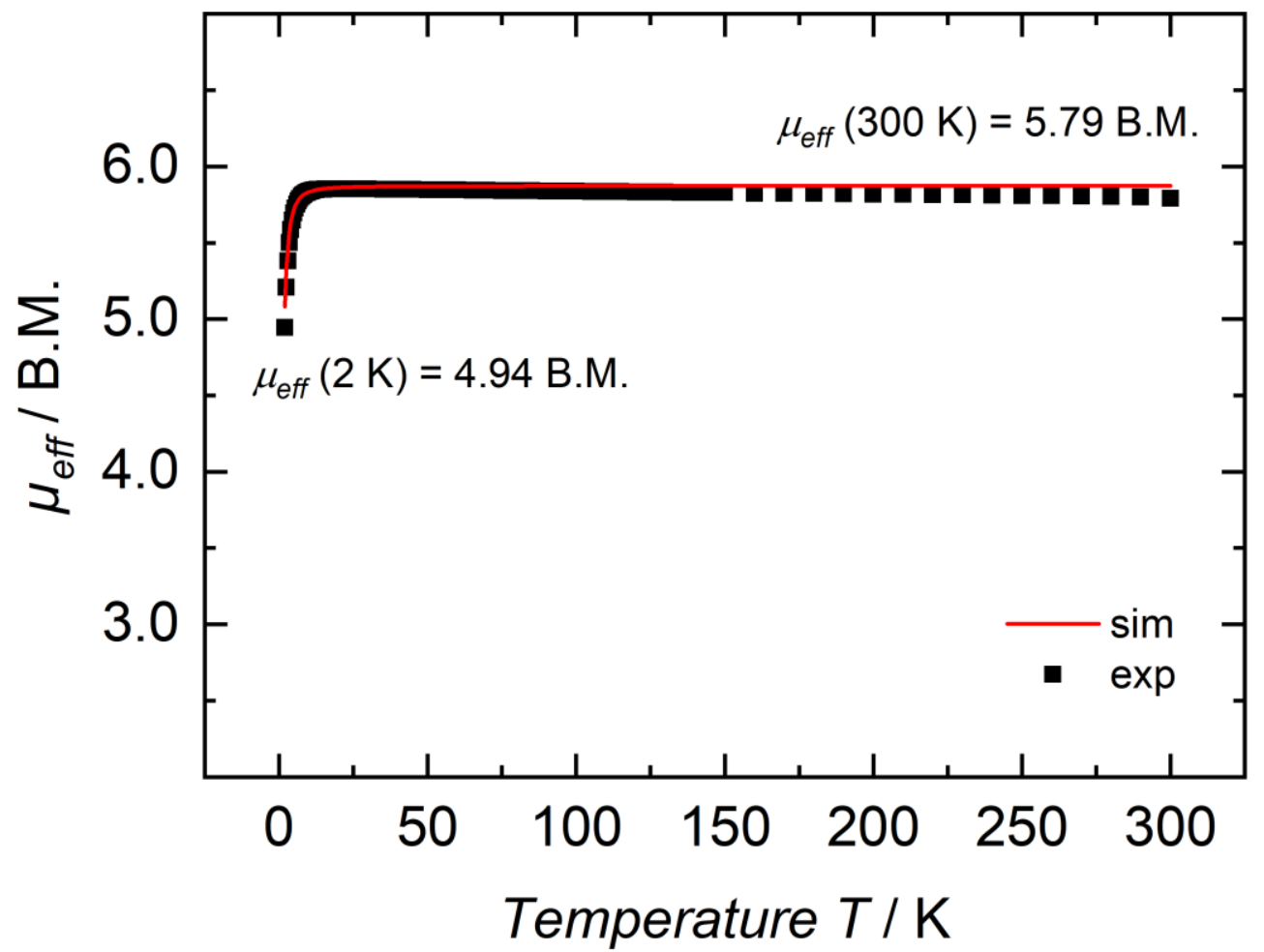

Figure S19. Temperature-dependent SQUID magnetization data of a powder sample of $\mathbf{2}^{\text {NO3 }}$ (black squares) and its simulation (red trace), recorded with an applied magnetic field of $1 \mathrm{~T}$. Simulation parameters: $S=2.5,|D|=0.59 \mathrm{~cm}^{-1}, E / D=0.15, g_{\text {avg }}=1.99$. 


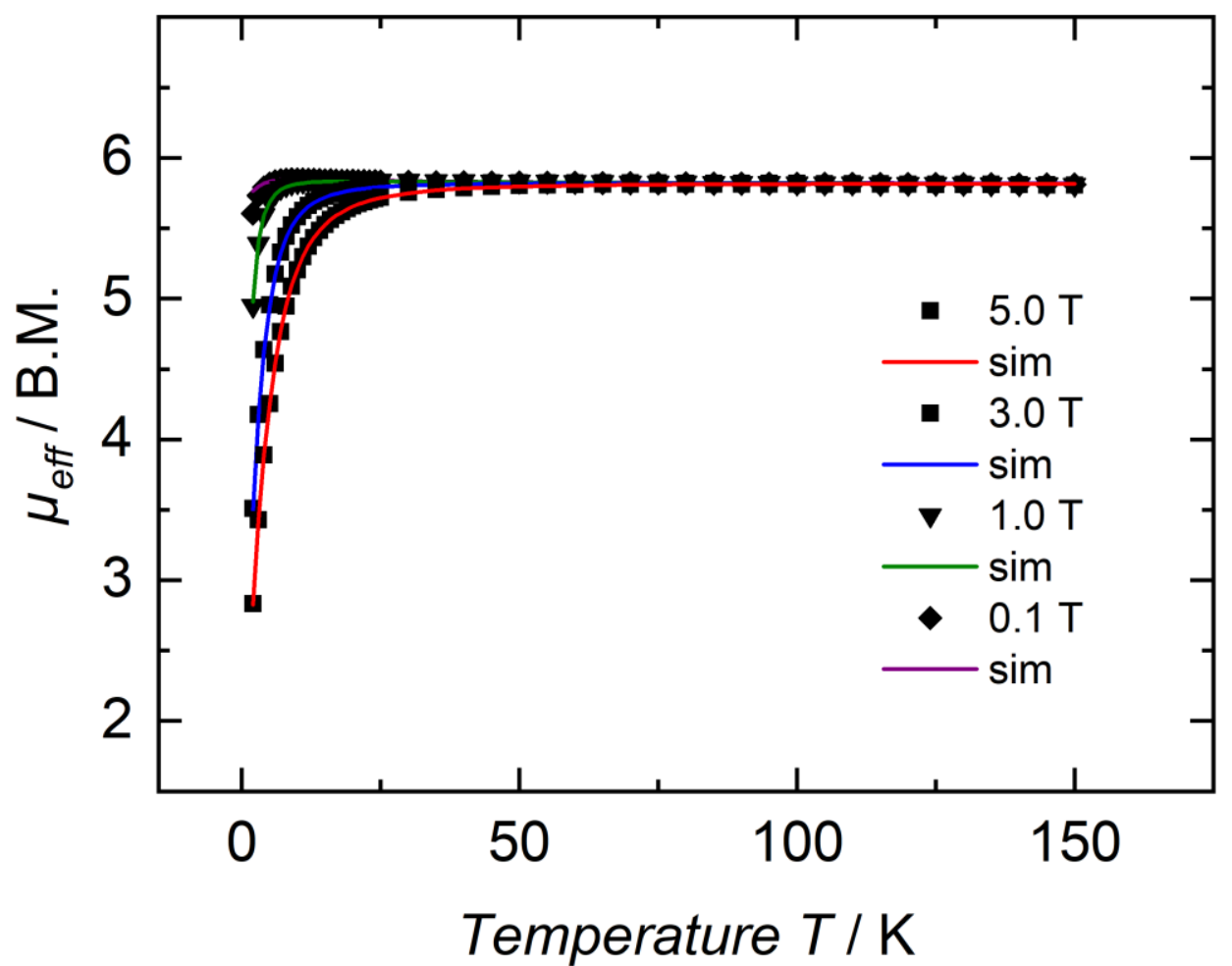

Figure S20. VT-VF SQUID magnetization data of a powder sample of $\mathbf{2}^{\mathrm{NO3}}$ at $5.0 \mathrm{~T}$ (black square) and its simulation (red trace), 3.0 T (black circle) and its simulation (blue trace), $1.0 \mathrm{~T}$ (black triangle) and its simulation (green trace), $0.1 \mathrm{~T}$ (black diamond) and its simulation (purple trace). Simulation parameters: $S=2.5,2 \mathrm{zJ}=1.05 \mathrm{~cm}^{-1}, D=+1.53 \mathrm{~cm}^{-1}, E / D=0.15, g_{\text {avg }}=1.97$. 
Table S1. X-ray crystallographic data for $2^{\mathrm{OA} \cdot} \mathrm{C}_{7} \mathrm{H}_{8}, \mathbf{2}^{\mathrm{NO}_{3} \cdot} \mathrm{C}_{7} \mathrm{H}_{8}$ and 3 .

\begin{tabular}{|c|c|c|c|}
\hline & $\mathbf{2}^{\mathbf{O A c} \cdot} \cdot \mathrm{C}_{7} \mathrm{H}_{8}$ & $\mathbf{2}^{\mathrm{NO}_{3} \cdot} \mathrm{C}_{7} \mathrm{H}_{8}$ & 3 \\
\hline Empirical formula & $\mathrm{C}_{48} \mathrm{H}_{67} \mathrm{FeN}_{4} \mathrm{O}_{2}$ & $\mathrm{C}_{46} \mathrm{H}_{64} \mathrm{FeN}_{5} \mathrm{O}_{3}$ & $\mathrm{C}_{39} \mathrm{H}_{58} \mathrm{~N}_{4}$ \\
\hline Formula weight & 787.90 & 790.87 & 582.89 \\
\hline Temperature & $100(1) \mathrm{K}$ & $100(1) \mathrm{K}$ & 100(1) K \\
\hline Wavelength & $0.71073 \AA$ & $0.71073 \AA$ & $0.71073 \AA$ \\
\hline Crystal system & Monoclinic & Monoclinic & Monoclinic \\
\hline Space group & $\mathrm{P} 2{ }_{1} / \mathrm{c}$ & $\mathrm{P} 2{ }_{1} / \mathrm{c}$ & $\mathrm{P} 2{ }_{1} / \mathrm{c}$ \\
\hline \multicolumn{4}{|l|}{ Cell constants: } \\
\hline$a$ & $18.9540(16) \AA$ & $9.4323(8)$ & $15.3893(13) \AA$ \\
\hline$b$ & $12.2891(11) \AA$ & $25.222(2)$ & $16.2938(14) \AA$ \\
\hline$c$ & 20.8553(18) $\AA$ & 18.4994(17) & $14.0288(11) \AA$ \\
\hline $\bar{\beta}$ & $116.527(4)^{\circ}$ & $99.566(5)$ & $97.962(4)^{\circ}$ \\
\hline Volume & $4346.4(7) \AA^{3}$ & $4339.8(6) \AA^{3}$ & $3483.8(5) \AA^{3}$ \\
\hline $\bar{Z}$ & 4 & 4 & 4 \\
\hline Density (calculated) & $1.204 \mathrm{~g} / \mathrm{cm}^{3}$ & $1.210 \mathrm{~g} / \mathrm{cm}^{3}$ & $1.111 \mathrm{~g} / \mathrm{m}^{3}$ \\
\hline $\begin{array}{l}\text { Absorption } \\
\text { coefficient }\end{array}$ & $0.389 \mathrm{~mm}^{-1}$ & $0.392 \mathrm{~mm}^{-1}$ & $0.065 \mathrm{~mm}^{-1}$ \\
\hline $\mathrm{F}(000)$ & 1700.0 & 1700.0 & 1280.0 \\
\hline
\end{tabular}




\begin{tabular}{|c|c|c|c|}
\hline Crystal size & $\begin{array}{c}0.49 \times 0.29 \times 0.22 \\
\mathrm{~mm}^{3}\end{array}$ & $\begin{array}{c}0.12 \times 0.06 \times 0.01 \\
\mathrm{~mm}^{3}\end{array}$ & $\begin{array}{c}0.45 \times 0.25 \times 0.1 \\
\mathrm{~mm}^{3}\end{array}$ \\
\hline $\begin{array}{l}\text { Theta range for data } \\
\text { collection }\end{array}$ & 2.402 to $55.12^{\circ}$ & 2.756 to $55.258^{\circ}$ & 2.672 to $52.846^{\circ}$ \\
\hline Index ranges & $\begin{array}{l}-23 \leq \mathrm{h} \leq 24 \\
-15 \leq \mathrm{k} \leq 15 \\
-27 \leq 1 \leq 27\end{array}$ & $\begin{array}{l}-12 \leq \mathrm{h} \leq 12 \\
-32 \leq \mathrm{k} \leq 32 \\
-24 \leq 1 \leq 22\end{array}$ & $\begin{array}{l}-19 \leq \mathrm{h} \leq 19 \\
-20 \leq \mathrm{k} \leq 18 \\
-17 \leq 1 \leq 17\end{array}$ \\
\hline Reflections collected & 87287 & 73589 & 41149 \\
\hline $\begin{array}{l}\text { Independent } \\
\text { reflections }\end{array}$ & $\begin{array}{c}10007[\mathrm{R} \text { (int) }= \\
0.0505]\end{array}$ & $\begin{array}{c}9851[\mathrm{R}(\mathrm{int})= \\
0.0917]\end{array}$ & $\begin{array}{c}7155[\mathrm{R}(\mathrm{int})= \\
0.0549]\end{array}$ \\
\hline Absorption correction & $\begin{array}{l}\text { Semi-empirical from } \\
\text { equivalents }\end{array}$ & $\begin{array}{c}\text { Semi-empirical from } \\
\text { equivalents }\end{array}$ & $\begin{array}{c}\text { Semi-empirical from } \\
\text { equivalents }\end{array}$ \\
\hline $\begin{array}{l}\text { Max. and min. } \\
\text { transmission }\end{array}$ & & & \\
\hline Refinement method & $\begin{array}{l}\text { Full-matrix least- } \\
\text { squares on } \mathrm{F}^{2}\end{array}$ & $\begin{array}{l}\text { Full-matrix least- } \\
\text { squares on } \mathrm{F}^{2}\end{array}$ & $\begin{array}{c}\text { Full-matrix least- } \\
\text { squares on } \mathrm{F}^{2}\end{array}$ \\
\hline $\begin{array}{c}\text { Data / restraints / } \\
\text { parameters }\end{array}$ & $10007 / 0 / 567$ & $9851 / 0 / 509$ & $7155 / 0 / 400$ \\
\hline $\begin{array}{c}\text { Goodness-of-fit on } \\
\qquad \mathrm{F}^{2}\end{array}$ & 1.021 & 1.100 & 1.027 \\
\hline $\begin{array}{l}\text { Final R indices } \\
{[\mathrm{I}>2 \operatorname{sigma}(\mathrm{I})]}\end{array}$ & $\begin{array}{c}\mathrm{R}_{1}=0.0367, \mathrm{wR}_{2}= \\
0.0933\end{array}$ & $\begin{array}{c}\mathrm{R}_{1}=0.1259, \mathrm{wR}_{2}= \\
0.03108\end{array}$ & $\begin{array}{c}\mathrm{R}_{1}=0.0422, \mathrm{wR}_{2}= \\
0.1011\end{array}$ \\
\hline
\end{tabular}




\begin{tabular}{|c|c|c|c|}
\hline R indices (all data) & $\mathrm{R}_{1}=0.0445, \mathrm{wR}_{2}=$ & $\mathrm{R}_{1}=0.1723, \mathrm{wR}_{2}=$ & $\mathrm{R}_{1}=0.0572, \mathrm{wR}_{2}=$ \\
& 0.0988 & 0.3421 & 0.1094 \\
\hline $\begin{array}{c}\text { Largest diff. peak and } \\
\text { hole }\end{array}$ & $0.61 /-0.41 \mathrm{e} \cdot \AA^{-3}$ & $2.41 /-0.95 \mathrm{e} \AA^{-3}$ & $0.26 /-0.24 \mathrm{e} \cdot \AA^{-3}$ \\
\hline
\end{tabular}




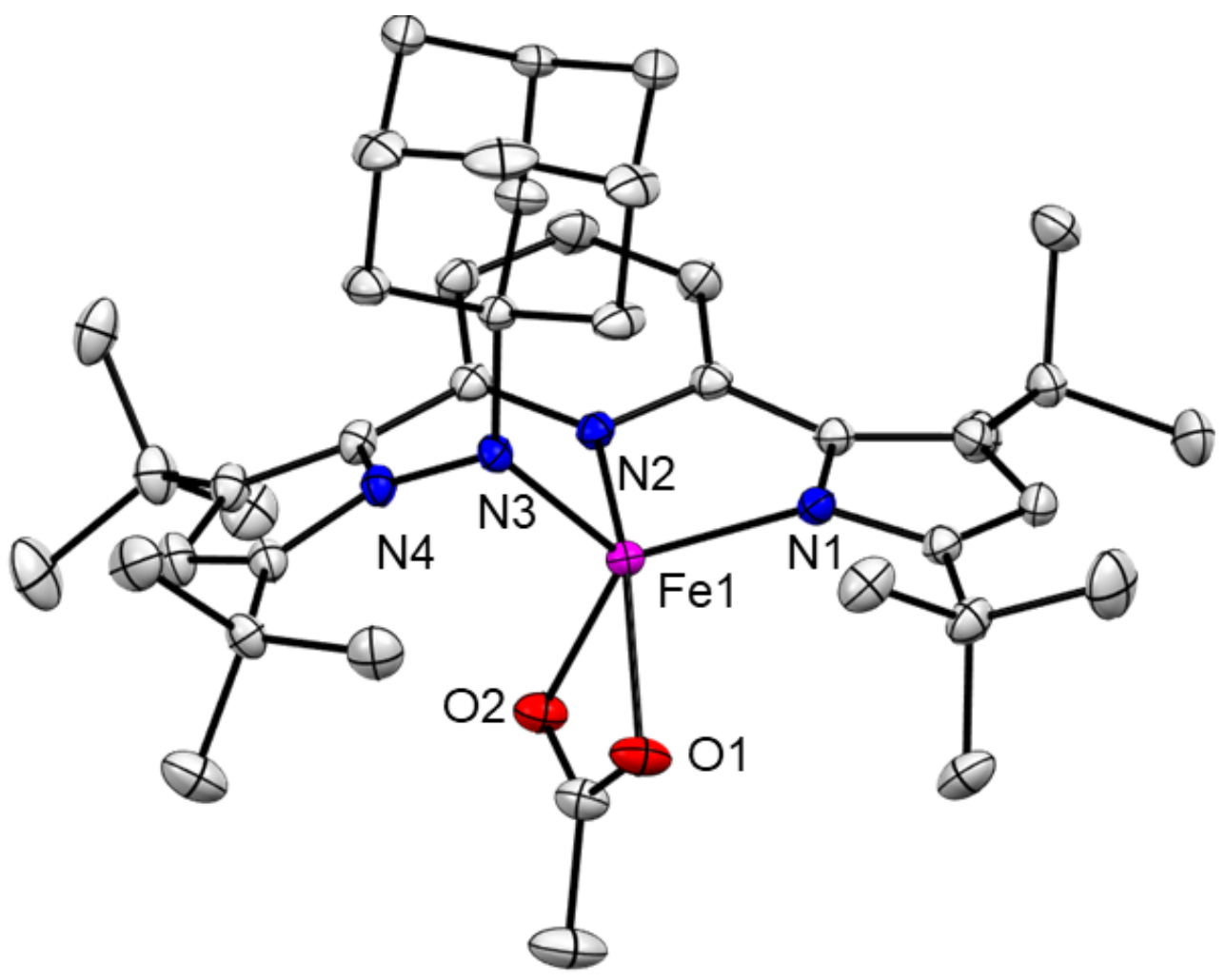

Figure S21. Solid-state molecular structure of $\mathbf{2}^{\mathbf{O A c}} \cdot \mathrm{C}_{7} \mathrm{H}_{8}$ with $50 \%$ probability ellipsoids. Cocrystallized $\mathrm{C}_{7} \mathrm{H}_{8}$ molecule and hydrogens not shown for clarity purposes. Selected bond lengths $(\AA):$ Fe1-N1 = 1.988(9), Fe1-N2 = 2.057(9), Fe1-N3 = 1.909(9), Fe1-O1 = 2.102(9), Fe1-O2 = 2.075(9), N3-N4 = 1.418(9). 


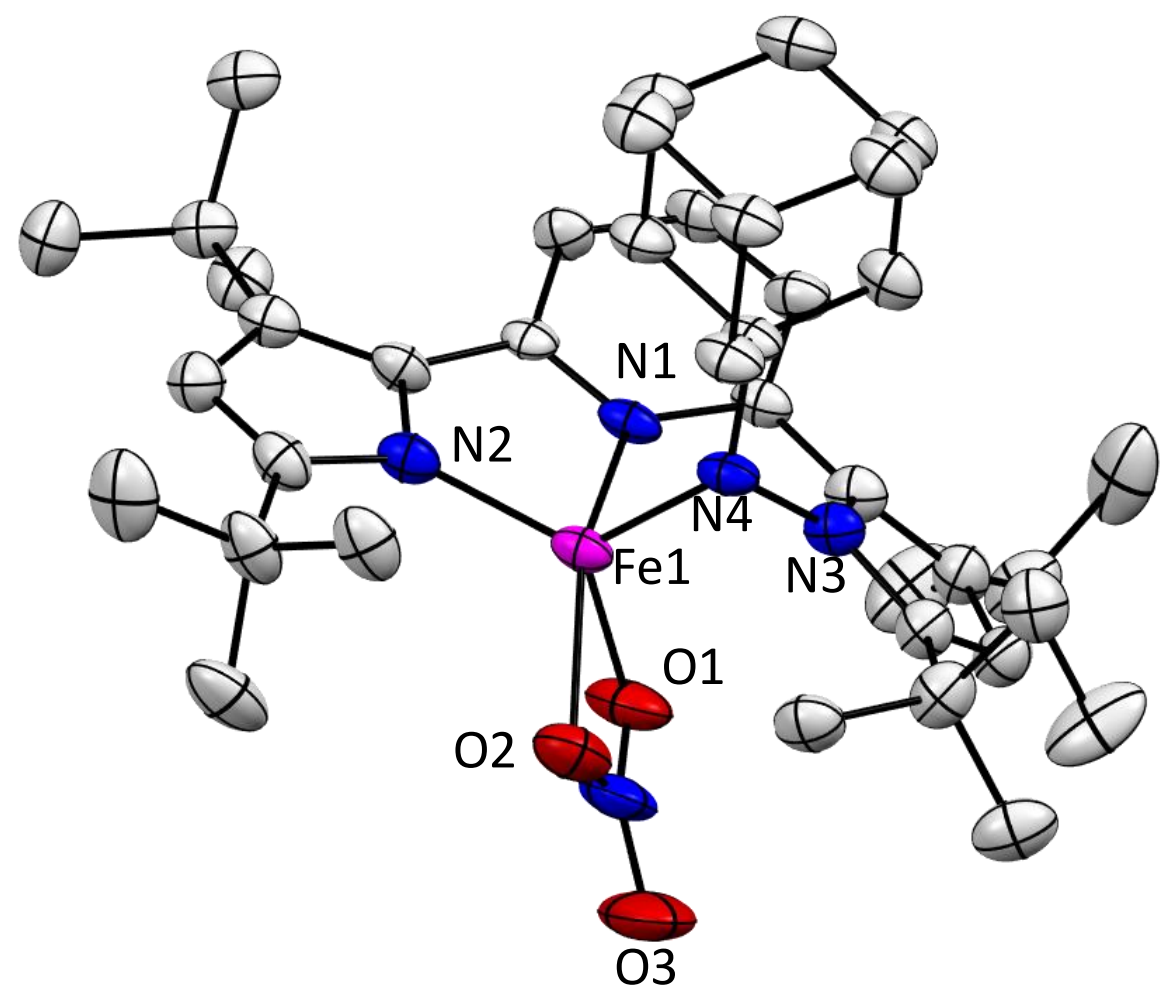

Figure S22. Solid-state molecular structure of $\mathbf{2}^{\mathrm{NO}} \cdot \mathrm{C}_{7} \mathrm{H}_{8}$ with $50 \%$ probability ellipsoids for connectivity purposes. Co- crystallized $\mathrm{C}_{7} \mathrm{H}_{8}$ molecule not shown for clarity purposes. 


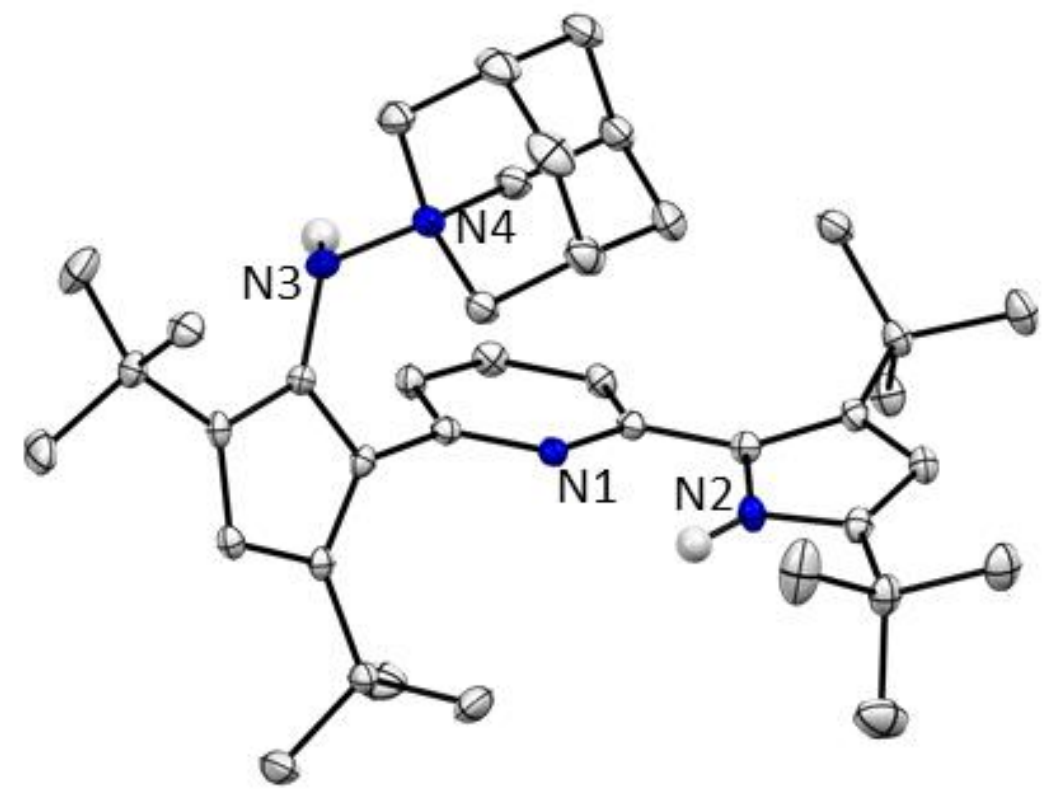

Figure S23. Solid-state molecular structure of $\mathbf{3}$ with $50 \%$ probability ellipsoids. Hydrogens atoms other than the ones for the pyrrole and hydrazine units are not shown for clarity purposes. 

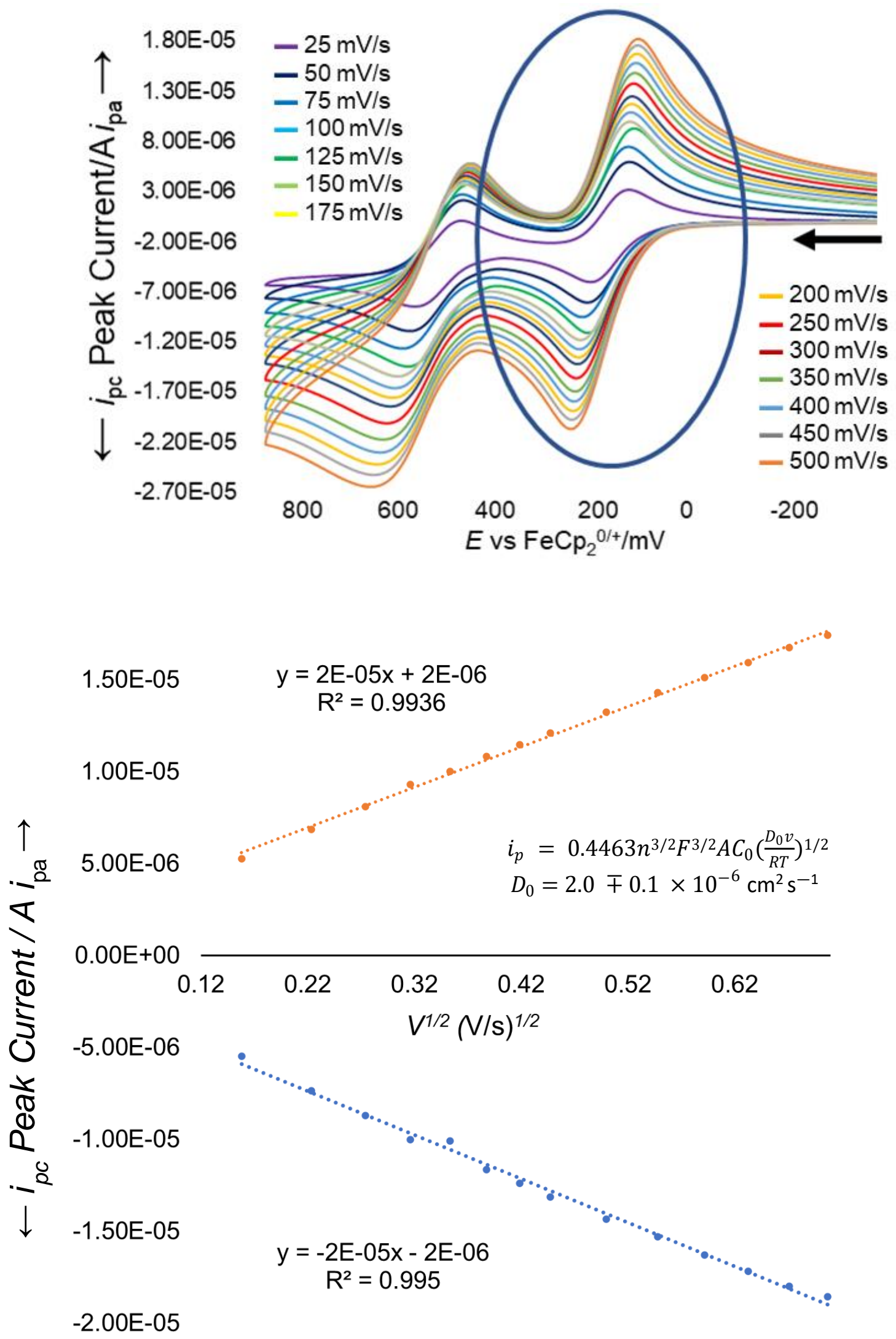
$n=$ number of electrons

$F=$ Faraday's constant

$D_{0}=$ diffusion coefficient $\left(\mathrm{cm}^{2} \mathrm{~s}^{-1}\right)$

$v=$ scan rate $\left(\mathrm{V} \mathrm{m}^{2} \mathrm{~s}^{-1}\right)$

$A=$ surface area of the electrode $\left(A=0.0707 \mathrm{~cm}^{2}\right)$

$C_{0}=$ bulk concentration of redox-active species $\left(\mathrm{mol} \mathrm{cm}{ }^{3}\right)$

$i_{p}=$ peak current

$$
i_{p}=0.4463 n^{3 / 2} F^{3 / 2} A C_{0}\left(\frac{D_{0} v}{R T}\right)^{1 / 2}
$$$$
D_{0}=2.0 \mp 0.1 \times 10^{-6} \mathrm{~cm}^{2} \mathrm{~s}^{-1}
$$

Figure S24. Cyclic Voltammogram for 1 (0.1 mM solution in DCM) were collected between 25$500 \mathrm{mV} / \mathrm{s}$ with $[\mathrm{TBA}]\left[\mathrm{PF}_{6}\right]$ as the supporting electrolyte $(0.1 \mathrm{M}$ solution in DCM) and referenced against the $\mathrm{FeCp}_{2}{ }^{0 /+}$ couple (Pt working electrode, Pt counter electrode, Pt wire pseudo-reference electrode). The diffusion coefficient $\left(D_{0}\right)$ was obtained using the Randles-Ševčík equation as described above. ${ }^{13}$ The plot of $i_{\mathrm{p}} \mathrm{vs} .(\mathrm{V} / \mathrm{s})^{1 / 2}$ is linear, indicating that the oxidation event at 0.244 V for $\mathbf{1}$ is diffusion controlled (scan rates $(\mathrm{mV} / \mathrm{s})=25,50,75,100,125,150,175,200,250,300$, 350, 400, 450 and 500). 


\section{References}

(1) Bill, E. EPR Programeview 2019.

(2) Bill, E. EPR Programesim 2019.

(3) Gaffney, B. J.; Silverstone, H. J.: Simulation of the EMR Spectra of High-Spin Iron in Proteins. In EMR of Paramagnetic Molecules; Berliner, L. J., Reuben, J., Eds.; Springer US: Boston, MA, 1993; pp 1-57.

(4) Bill, E. Mössbauer Program Mcal 2019.

(5) Bill, E. Mössbauer Program Mfit 2019.

(6) Bain, G. A.; Berry, J. F. Diamagnetic Corrections and Pascal's Constants. J. Chem. Ed. 2008, 85, 532-536.

(7) Bill, E. E. Bill, SQUID ProgramjulX2, 2019.

(8) Bruker. A.P.E.X. and AXS SAINT. Bruker AXS Inc., M., WI, 2004.

(9) Bruker. SHELXTL. Bruker AXS Inc., M., WI, 2009.

(10) Blessing, R. An empirical correction for absorption anisotropy. Acta Crystallograph. Sect. A, 1995, 51,33-38.

(11) Sheldrick, G. M. T., Version 2008/4. Univ. Göttingen, Ger. 2008.

(12) Sheldrick, G. A short history of SHELX. Acta Crystallograph. Sect. A, 2008, 64, 112-122.

(13) Bard, A. J. F., L. R. Electrochemical Methods, 2nd ed.; John Wiley \& Sons, 2001. 